\title{
No Means No, Or Does It? A Comparative Study of the Right to Refuse Treatment in a Psychiatric Institution
}

Mehgan Gallagher*

\begin{abstract}
Around the world, people with mental disabilities are subject to many types of behavioral therapies against their will, including medications and restraints. This is especially true of people who are institutionalized. These intrusions are in violation of fundamental international human rights principles. People with mental disabilities are often stripped of many of their basic rights, including the right to determine what is done to their bodies. This article compares the prevailing law on the right to refuse treatment for people with mental disabilities in an institutional setting in three different nations on three continents, specifically in the United States, Kenya, and Brazil.
\end{abstract}

\section{INTRODUCTION}

All around the world, people with mental disabilities ${ }^{1}$ are forced to take medication, are restrained, and are subject to other types of behavioral therapy against their will. ${ }^{2}$ This is especially true of people who are institutionalized. ${ }^{3}$ Many of these intrusions are violations of international human rights principles. Pain inflicted in the name of treatment is increasingly recognized as a violation of international law. ${ }^{4}$ People with mental disabilities are often stripped of many of their basic rights, ${ }^{5}$ including the right to determine what is done to their bodies. ${ }^{6}$ For over four decades, ${ }^{7}$ lawyers in the United States have argued that involuntarily committed psychiatric patients have a right to refuse treatment. ${ }^{8}$ This argument is mainly based on the Fifth, Sixth, Eighth, Ninth and Fourteenth Amendments of the United States Constitution, as well as on state common law and constitutional law. ${ }^{9}$ There

* (C) 2016 Mehgan Gallagher. The author would like to thank Professor Michael L. Perlin for his invaluable mentoring and editing assistance and Christina Glon for her never-ending editing and encouragement.

${ }^{1}$ I use the term "people" or "persons with disabilities" throughout this article instead of other accepted terms such as "people with a mental illness" or "disabled people" because I believe it more carefully defines an individual as a person first and as having a disability second.

${ }^{2}$ Eric Rosenthal \& Laurie Ahern, When Treatment is Torture: Protecting People with Disabilities Detained in Institutions, 19 Hum. RTS. BR. 13, 13 (2011-2012) [hereinafter Rosenthal \& Ahern, Institutions].

${ }^{3}$ Kevin Newman, Sounding the Mind: On the Discriminatory Administration of Psychotropics Against the Will of the Institutionalized, 22 S. CAL. Rev. L \& Soc. Just. 265, 265 (2012-2013).

${ }^{4}$ Rosenthal \& Ahern, Institutions, supra note 2, at 13.

${ }^{5}$ Manfred Nowak (Special Rapporteur of the Human Rights Counsel on torture and other cruel, inhuman or degrading treatment or punishment), Interim Report on Torture and other cruel, inhuman or degrading treatment or punishment, transmitted by Note of the Secretary-General, U.N. Doc. A/63/175, 53 (July 28, 2008) [hereinafter the Nowak Interim Report on Torture].

6 Janos Fiala-Butora, Disabling Torture: The Obligation to Investigate Ill-Treatment of Persons with Disabilities, 45 Colum. Hum. Rts. L. R. 214, 216 (2013-2014).

${ }^{7}$ See e.g., Mackey v. Procunier, 477 F.2d 877 (9th Cir. 1973).

8 James B. (Jim) Gottstein, Involuntary Commitment and Forced Psychiatric Drugging in the Trial Courts: Rights Violations As A Matter of Course, 25 Alaska L. Rev. 51, 51 (2008).

${ }^{9}$ See generally Michael L. Perlin, Mental Disability Law: Civil and Criminal ch. 3B (2d ed. 1999) [hereinafter Perlin, Mental Disability Law]. 
are also United Nations resolutions as well as regional human rights laws that recognize the right to refuse treatment. ${ }^{10}$

This article compares the prevailing law on the right to refuse treatment for people with mental disabilities in an institutional setting in three different nations in three different regions: North America, Africa, and Latin America, and specifically the United States, Kenya, and Brazil. I have chosen countries in Africa and Latin America because these are two regions with an established regional system of international human rights and disability law, ${ }^{11}$ and little has been written on the right to refuse treatment in these countries. ${ }^{12}$ The United States, with a robust area of case law on the subject, is used as a comparator.

First, I will discuss the significance of the right to refuse treatment and the historical factors that have contributed to making it a highly contentious issue. Next, I will consider the United Nations Convention on the Rights of Persons with Disabilities (CRPD), as well as other United Nations documents, to lay a framework for understanding international mental disability law and the right to refuse treatment. For comparison purposes, I will briefly discuss the law in the United States regarding the right to refuse treatment and will compare the right to refuse treatment in Kenya and Brazil. Finally, I will conclude with some thoughts on future steps to ensure that people with mental disabilities in institutional settings do have the right to refuse treatment so that "no" really will mean no.

\section{History}

\section{A. What is Treatment?}

\section{Continuum of Intrusiveness}

Any discussion of the right to refuse treatment must first begin by explaining what is meant by the term "treatment." There are many different types of treatment. Noted scholar and professor Bruce J. Winick looks at different types of treatment on a "continuum of intrusiveness" scale based on the treatment's potential to interfere with an individual's physical or mental processes. ${ }^{13}$ The scale of intrusiveness is determined by the following factors: (1) the nature, extent, and duration of the effects of the technique; (2) the extent to which

${ }^{10}$ See e.g., G.A. Res. 46/119, 1991 Principles for the Protection of Persons with Mental Illness and the Improvement of Mental Health Care (Dec. 17, 1991) [hereinafter MI Principles]; see also, infra note 142 and accompanying text (discussing the ICCPR).

11 "In the specific area of mental disability law, there is now a remarkably robust body of case law from the European Court on Human Rights (ECtHR), some significant and transformative decisions from the Inter-American Commission on Human Rights (IACHR), and at least one major case from the African Commission on Human Rights (African Commission)." Michael L. Perlin, Promoting Social Change in Asia and the Pacific: The Need for a Disability Rights Tribunal to Give Life to the UN Convention on the Rights of Persons with Disabilities, 44 Geo. Wash. InT'L L. Rev. 1, 1 (2012). Asia does not as of yet have a regional tribunal. In Asia and the Pacific region, there is no such body of case law like what can be found in the European, Inter-American, and African systems. The Association of Southeast Asian Nations (ASEAN) charter refers to human rights; however it cannot be recognized as a significant enforcement tool in human rights law and policy. See generally, $i d$. (discussing the need for a regional tribunal in Asia and the Pacific).

${ }^{12}$ In my research, I found very little scholarship on the right to refuse treatment in Africa and South America, and even less in Kenya and Brazil specifically. See e.g., Jennifer Fischer, A Comparative Look at the Right to Refuse Treatment for Involuntarily Hospitalized Persons with a Mental Illness, 29 Hastings InT'L \& CoMP. L. Rev. 153, 155 (2005-2006) (examining the right to refuse in a variety of countries including some in Africa and South America). There has been some scholarship about the right to refuse in South Africa (see e.g., Alfred Allan \& Marietjie Allan, The Right of Mentally Ill Patients in South Africa to Refuse Treatment, 114 S. AfricAn L.J. 724 (1994)) but there has been next to nothing written about Kenya and Brazil within the context of right to refuse, especially since the ratification of the United Nations Convention on the Rights of Persons with Disabilities. See United Nations Convention on the Rights of Persons with Disabilities, G.A. Res. 61/106, at 27, U.N. Doc. A/Res/61/106 (Dec. 13, 2006) [hereinafter CRPD]; see also infra note 122 and accompanying text (discussing the importance of the Convention).

13 See generally Bruce J. Winick, The Right to Refuse Mental Health Treatment: A First Amendment Perspective, 44 U. Miami L. Rev. 1 (1989). 
the effects of the technique can be avoided; and (3) the extent to which the technique requires actual physical intrusion. ${ }^{14}$

\section{Psychotherapy and Behavioral Therapy}

Psychotherapy, referring to the therapeutic interaction between a trained professional and a patient, is considered by most to be the least intrusive form of therapy as it can easily be resisted by the patient and does not involve any physical intervention from the therapist. ${ }^{15}$

Behavioral therapy, on the other hand, is considered to be minimally intrusive, both in theory and practice, and includes both positive (reinforcing good behavior) and aversive therapy (using unpleasant stimuli to discourage unwanted behavior). ${ }^{16}$ Behavioral therapy is considered more intrusive than psychotherapy because behavioral therapy may involve consequences which may be physically painful, psychologically harmful, or difficult to resist. However behavioral therapy conducted via positive enforcement is considered to be less intrusive than any type of medication, seclusion, and/or restraint. Behavioral therapy is commonly seen in the treatment of individuals with mental disabilities in prisons. ${ }^{17}$

\section{Psychotropic Medications}

Psychotropic medication ${ }^{18}$ is considered to be the next least intrusive treatment on Winick's continuum and has been at the center of most of the right to refuse treatment cases in the United States ${ }^{19}$ due to its frequent use in public mental health facilities. ${ }^{20}$

Many psychotropic medications trigger unwanted side effects. ${ }^{21}$ In fact, prior to the 1990 s, many antipsychotic drugs (especially those treating schizophrenia) caused significant side effects. ${ }^{22}$ Many patients who took these neuroleptics ${ }^{23}$ developed permanent and sometimes disabling neuromotor syndromes such as tardive dyskinesia. ${ }^{24}$

14 Note, Conditioning and Other Technologies Used to "Treat?" "Rehabilitate?" "Demolish?" Prisoners and Mental Patients, 45 S. CAL. L. Rev. 616, 619 (1972).

${ }^{15}$ Winick, supra note 13 , at 80.

${ }^{16}$ Id.; see also R. Schwitzgebel, Legal Aspects of the Enforced Treatment of Offenders (Dhew Pub. No. (Adm) 66, 1979).

${ }^{17}$ Winick, supra note 13, at 80; see generally, Henry Dlugacz \& Christopher Wimmer, Legal Aspects of Administering Antipsychotic Medications to Jail and Prison Inmates, 36 InT'L J. of LAw \& Psych. 213-228 (2013).

${ }^{18}$ When I refer to "psychotropic medication," I am also including antipsychotic medication although psychotropic and antipsychotic medications may have very different effects. See Winick, supra note 13, at 69.

19 See Michael L. Perlin, Decoding Right to Refuse Treatment Law, 16 InT'L J.L. \& Psychiatry 151, 177 (1993) [hereinafter Perlin, Decoding] (tracing the development of case law with respect to the right to refuse antipsychotic medication in various litigation settings).

${ }^{20}$ Winick, supra note 13 , at 70.

${ }^{21}$ National Institute of Neurological Disorders and Stroke (updated April 16, 2014), available at http://www.ninds.nih.gov/ index.htm (last visited April 16, 2016); see also e.g., Jonas Robitscher, ECT and Invasive Therapies, in CRITICAL IssuES IN American Psychiatry and Law 303, 319-320 (Richard Rosner ed., 1982). "[T]he side effects of drugs can be more disabling than those of [electroconvulsive therapy and [the use of] injection tranquilization can be easily seen as much more intrusive and more drastic than other drug therapies." See Perlin, Mental Disability Law, supra note 9, at $\S 3$ B-10.3.

${ }^{22}$ Side effects can range from dry mouth, blurred vision and muscular spasms, tics, and involuntary movement, to neuroleptic malignant syndrome. Winick, supra note 13, at 71-72; see also Douglas Mossman, Unbuckling the Chemical Straightjacket: The Legal Significance of Recent Advancements in the Pharmacological Treatment of Psychosis, SAN DIEGO L. Rev. Vol. 39 1033, 1066 (2002).

23 The French psychiatrists Delay and Deniker coined the term "neuroleptic" in 1955. ANN BRADEN JOHNSON, Out OF Bedlam: The Truth About Deinstitutionalization 38-39 (1990). The pronounced effects of these drugs on many aspects of the nervous system led to their being termed "neuroleptics," a combination of two Greek words translating to nerve and to take hold. Dorland’s Illustrated Medical Dictionary 1210 (29th ed. 2000).

24 Tardive dyskinesia (TD) is a syndrome of long-standing or permanent abnormal involuntary movements that is most commonly caused by long-term use of typical antipsychotic (neuroleptic) drugs. Tardive dyskinesia presents clinically as involuntary movements of the tongue, facial, and neck muscles, upper and lower extremities, truncal musculature, or occasionally muscle groups that subserve breathing and swallowing including tongue protrusions, lip smacking, puckering of the lips, 
Further, a small number of patients actually developed a severe, sometimes fatal reaction known as "neuroleptic malignant syndrome." 25

Treatment in the form of psychotropic medication has a high potential for overuse and nontherapeutic use, and is often administered despite the patient's objection. ${ }^{26}$ Its side effects, along with the fact that it is often times forcibly injected or otherwise administered, arguably make this form of treatment very intrusive. ${ }^{27}$

It is vital to note an important distinction here between an individual who voluntarily seeks help from a professional therapist and is subsequently prescribed medication and an individual who is in a psychiatric facility. An individual seeking treatment from a therapist who gives him a prescription, has the choice to politely decline or to go see another doctor. ${ }^{28}$ However, in an institution, a very different scenario occurs. Many times, individuals in institutions are forced to take medications against their will. If they do not comply, they often face injection, seclusion, restraint, or other forms of punishment. ${ }^{29}$

\section{Seclusion and Restraints}

People with mental disabilities are often subject to seclusion and restraints, either as a means of containing them or as a form of punishment. ${ }^{30}$ While the use of seclusion (and certainly restraints) is arguably very high on the scale of intrusiveness, it is hard to determine exactly where these fall on the continuum due to the relative degree of restrictiveness amongst the various forms of restraints. ${ }^{31} \mathrm{I}$ have chosen to place them between psychotropic medications and what I consider to be more physically intrusive methods of treatment including electroshock therapy and psychosurgery.

Seclusion is also used sometimes as a form of punishment for persons with mental disabilities in institutions. Seclusion and solitary confinement (i.e. physical isolation for 22-24 hours a day) are often used as forms of control over people with mental disabilities in institutions. Historically, solitary confinement was also used as a rehabilitation method for prisoners. ${ }^{32}$ Its side effects can be serious and include insomnia, confusion, and hallucinations. The former Special Rapporteur on the Convention Against Torture, Manfred Nowak, has concluded that seclusion and solitary confinement may constitute torture or ill-treatment. ${ }^{33} 34$

chewing movements, and rapid tic-like movements of the face. TD rarely occurs in young individuals who have been exposed to neuroleptics for fewer than three months. Steven E. Hyman et al., Handbook of Psychiatric Drug Therapy 35 (3d ed. 1995).

${ }^{25}$ This syndrome occurs in one-tenth to 1 percent of persons receiving neuroleptics, and "is characterized by the development of fever, rigidity, autonomic instability, altered consciousness, ... [elevated cardiac enzymes,] and raised WBC [white blood cell] count." Herbert Y. Meltzer \& S. Hossein Fatemi, Treatment of Schizophrenia, in The American PsychiATRIC Press Textbook of Pharmacology 760-61 (Alan F. Schatzberg \& Charles B. Nemeroff eds., 2d ed. 1998); see also, Hyman ET AL., supra note 24 , at 34 .

${ }^{26}$ Winick, supra note 13 , at 69-76.

${ }^{27}$ See Riggins v. Nevada, 504 U.S. 127 (1992) (recognizing the intrusive nature of antipsychotic drugs and their side effects in concluding that the forcible injection of medication represents a substantial interference with the person's liberty, and, in the case of antipsychotic drugs, that interference is "particularly severe").

${ }^{28}$ See A. A. Stone, The Right to Refuse Treatment: Why Psychiatrists Should and Can Make It Work, 38 Archives Gen. Psychiatry 358 (1981).

${ }^{29}$ See generally, Rosenthal \& Ahern, Institutions, supra note 2; see also Fiala-Butora, supra note 6, at 234-236.

${ }^{30}$ Fiala-Butora, supra note 6, at 234-236.

${ }^{31}$ Grant Harris et al., Staff and Patient Perceptions of the Least Restrictive Alternatives for the Short-term Control of Disturbed Behavior, 17 J. Psychiatry \& L. 239, 259 (1989) ("Mechanical restraint combined with constant observation was clearly the most intrusive component, followed in descending order of intrusiveness by seclusion, sedative injection, loss of clothing, a sedative pill and manual restraint.").

32 The Nowak Interim Report on Torture, supra note 5.

${ }^{33} I d$.

${ }^{34}$ Fiala-Butora, supra note 6, at 236; in certain circumstances, solitary confinement can rise to the level of torture - such as its use for the purpose of punishment. See also Juan Mendez (Special Rapporteur of the Human Rights Counsel on torture and other cruel, inhuman or degrading treatment or punishment), Interim Report on Torture and cruel, inhuman or degrading treatment or punishment, transmitted by note of the Secretary-General, U.N. Doc. A/66/268, 172 (Aug. 5, 2011) at 78. 
Restraints can take on many forms including the use of leather straps, tying people to bed frames, and restraining people to caged beds. ${ }^{35}$ People with mental disabilities have also been found chained to trees, ${ }^{36}$ walls, ${ }^{37}$ or outdoor cages. ${ }^{38}$ Side effects of prolonged restraint not only include exaggerated psychological damage, but can also lead to physical long-term harm including muscle atrophy, life-threatening deformities, and organ failure. ${ }^{39}$ According to Nowak, "there can be no therapeutic justification for the prolonged use of restraints, which may amount to torture or ill-treatment." 40

\section{Electroconvulsive Therapy (“ECT")}

Electroconvulsive therapy ("ECT") is next in line on the scale of intrusiveness, due to its side effects and the direct effect on thought processes. Side effects of ECT may include long- and short-term memory loss, nausea, vomiting, headache, muscle ache or spasms, and serious heart problems. ${ }^{41}$

ECT can be administered either in its modified or unmodified form. The modified form involves the use of anesthesia and muscle relaxants. This method, although still controversial, is much more widely accepted than ECT in its unmodified form, which does not involve anesthesia or muscle relaxants. In fact, Professor Michael L. Perlin, a leading legal scholar in the area of disability law, calls unmodified ECT "particularly barbaric." 42

The Council of Europe's (COE) Committee for the Prevention of Torture (CPT), in its eighth General Report, recommended that ECT always be administered in a modified form. ${ }^{43}$ In some nations, unmodified ECT is still used, ${ }^{44}$ although prevailing professional wisdom does not condone it. ${ }^{45}$ In some circles, ECT has developed a

35 See e.g., Mental Disability Advocacy Ctr., Cage Beds: Inhuman and Degrading Treatment in Four EU Accession Countries, 18-19 (2003) (discussing the wide variation in restraints used among institutions studied).

36 See e.g., Human Rights Watch Report, “Like a Death Sentence:" Abuses Against Persons with Mental Disabilities in Ghana, (October 2, 2012), https://www.hrw.org/report/2012/10/02/death-sentence/abuses-against-persons-mental-disabilitiesghana (last visited April 16, 2016) (detailing the use of chains to restrain people with mental disabilities in prayer camps in Ghana for up to 23 hours a day).

${ }^{37}$ Eva Szeli, International Mental Disability Law: The Central \& Eastern European Experience, 21 N.Y.L. SCH. J. INT’L \& Comp. L. 349, 353 (2002).

${ }^{38}$ See Michael Perlin, International Human Rights Law and Comparative Mental Disability Law: the Universal Factors, 34 Syracuse J. InT'L \& COM. L. 333, 347 (2007) [hereinafter Perlin, the Universal Factors] (discussing women found chained to outdoor cages in Nicaragua); see also, Press Release, Amnesty Int'l, Bulgaria: Disabled Women Condemned to 'Slow Death' (Oct. 10, 2001), http://www.amnesty.org.uk/press-releases/bulgaria-disabled-womens-rightss-rightss-rightss-rightss-rightssrights-condemned (last visited April 16, 2016) (discussing women found chained to outdoor cages in Bulgaria).

39 Eric Rosenthal \& Ahern, Torment not Treatment: Serbia's Segregation and Abuse of Children and Adults with Disabilities, 2007, 25 [hereinafter Rosenthal \& Ahern, Serbia's Segregation] (citing World Health Organization, TREATMENT OF MENTAL DISORDERS: A REVIEW OF EFFECTIVENESS 19 (Norman Sartorius, Giovanni de Girolamo, Gavin Andres, G. Allen German, and Leon Eisenberg, eds., 1993), 349, 365).

40 The Nowak Interim Report on Torture, supra note 5. However, the European Court considered the use of restraints in a psychiatric institution in the infamous Herczegfalvy v. Austria case and concluded that it would not find restraints to constitute inhuman treatment, despite the troubling length of their application, if their use was a "therapeutic necessity." Herczegfalvy v. Austria, App. No. 10533/83, 15 Eur. H.R. Rep. 437, 458 (1992).

${ }^{41}$ Winick, supra note 13, at 67-68; See also generally, The Mayo Clinic, "Tests and Procedures: Electroconvulsive Therapy (ECT)," http://www.mayoclinic.org/tests-procedures/electroconvulsive-therapy/basics/risks/prc-20014161 (last visited April 16, 2016).

42 Symposium: International Human Rights Law and the Institutional Treatment of Persons with Mental Disabilities: The Case of Hungary, 21 N.Y.L. SCH. J. INT'L \& CoMP. L. 339, 354 (2002) [hereinafter Symposium].

${ }^{43}$ Council of Europe: Committee for the Prevention of Torture, $8^{\text {th }}$ General Report of the European Committee for the Prevention of Torture and Inhuman or Degrading Treatment or Punishment (CPT) (Jan. 1-Dec. 31 1997) \39 (Aug. 31 , 1998), available at http://www.cpt.coe.int/en/annual/rep-08.htm (last visited April 16, 2016).

${ }^{44}$ For example, unmodified ECT is still permitted in that it is not legally prohibited in Bulgaria. Krassimir Kanev, State, Human Rights, and Mental Health in Bulgaria, 21 N.Y.L. ScH. J. INT'L \& Comp. L. 435, 460 (2002); see also, Rosenthal \& Ahern, Institutions, supra note 2, at 15 (discussing the use of unmodified ECT in Turkey).

${ }^{45}$ Kanev, supra note 44, at 460; see also, Michael L. Perlin and Meredith Schriver, "You That Hide Behind Walls": The Relationship Between the Convention on the Rights of Persons with Disabilities and the Convention Against Torture and the Treatment of Institutionalized Forensic Patients, in Torture and Ill-Treatment In Health-Care settings: 
reputation as a form of torture. It has been reportedly used to torture prisoners in Brazil, El Salvador, Morocco, and South Africa under apartheid. ${ }^{46}$ Many countries, including the United States, still use ECT but only in its modified form. ${ }^{47}$

\section{Psychosurgery}

Psychosurgery is widely considered to be the most intrusive form of treatment. It consists of the surgical removal or destruction of brain tissue with the intent of altering emotions and behavior. ${ }^{48}$ Psychosurgery is a direct intervention into the brain, which cannot be resisted by the patient, and surgically alters the individual's thoughts, feelings, behavior, and potentially his very identity. ${ }^{49}$ It is irreversible, as destroyed brain tissue does not regenerate, and permanent alteration in personality may result in some cases. ${ }^{50}$

This article will concentrate on the administration of psychotropic medication due to the fact that it is the modality of treatment most commonly used in in-patient psychiatric treatment facilities ${ }^{51}$ and because it is the subject of much of the right to refuse treatment case law. ${ }^{52}$

\section{B. The Debate Over the Fundamental Right to Refuse Treatment}

Professor Perlin considers the right to refuse treatment as the "pivotal issue in the determination of the future direction of the relationship between law and mental health." 53

There has long been a debate between physicians, concerned with treating patients considered to be ill, and patients' rights defenders, who advocate for patient autonomy and fundamental human rights. ${ }^{54}$ The former is generally referred to as the "medical model" and primarily focuses on health as a societal value with a corresponding right to treatment, ${ }^{55}$ while the latter is generally referred to as the "civil rights model" 56 and is founded on values of autonomy and equality. ${ }^{57}$

The "right to treatment" generally refers to an individual's constitutional right to receive treatment for a mental disability in a psychiatric institution. It is a minimum treatment standard that is meant to afford the individual with an opportunity to improve his or her mental condition. ${ }^{58}$

Compilation 195 (American University Center on Humanitarian Law ed. 2013) (discussing the CRPD and the Committee

Against Torture in forensic settings and torture in a disability rights context).

${ }^{46}$ Citizens Commission on Human Rights, Psychiatry Destroys Minds: Electroshock Pain and Fraud in the Name of Therapy, available at http://www.cchr.org/doctors/ect/eng/page20.htm (last visited April 16, 2016).

${ }^{47}$ Symposium, supra note 42.

${ }^{48}$ See generally, Vermont H. Mark \& Frank R. Ervin, Violence and the Brain (1970); Modern Concepts in Psychiatric Surgery (R. Hitchcock, T. Ballantine \& A. Meyerson eds. 1979); Operating on the Mind: the Psychosurgery Conflict (W. Gaylin, J. Meister, \& R. Neville eds. 1975).

49 Winick, supra note 13, at 65-66; see also generally, The Psychosurgery Debate: Scientific, Legal and ethical

Perspectives (E. Valenstein ed. 1980); Samuel I. Shuman, Psychosurgery and the Medical Control of Violence: Autonomy and Deviance (1977).

${ }^{50}$ Winick, supra note 13 , at 65.

${ }^{51}$ Kathleen Knepper, The Importance of Establishing Competence in Cases Involving the Involuntary Administration of Psychotropic Medications, 20 Law \& Psychol. Rev. 97 (1996).

${ }^{52}$ The issue of the right to refuse antipsychotic medication remains the most important and volatile area of the legal regulation of mental health practice. See generally, Alexander Brooks, The Right to Refuse Antipsychotic Medications: Law and Policy, 39 Rutgers L. Rev. 339 (1987); Sheldon Gelman, Mental Hospital Drugging: Atomistic and Structural Remedies, 32 Clev. St. L. Rev. 221 (1983-1984); Robert Plotkin, Limiting the Therapeutic Orgy: Mental Patients' Right to Refuse Treatment, 72 NW. U.L. Rev. 461 (1977).

${ }^{53}$ Perlin, Decoding, supra note 19 , at 8.

${ }^{54}$ Elyn R. Saks, Refusing Care: Forced Treatment and the Rights of the Mentally Ill 5-19 (2002).

${ }^{55}$ Caroline Gendreau, The Rights of Psychiatric Patients in the Light of the Principles Announced by the United Nations: A Recognition of the Right to Consent to Treatment?, 20 InT'L J. L. \& Psychiatry 259, 269 (1997).

${ }_{56}^{56}$ See Fischer, supra note 12, at 155.

${ }^{57}$ Gendreau, supra note at 55, at 269.

${ }^{58}$ See Wyatt v Stickney, 325 F. Supp. 781 (M.D. Ala. 1971). 
For proponents of the right to refuse treatment, there are two overarching issues at play: (1) the abuse of psychotropic medications, and (2) the assurance of patient autonomy. ${ }^{59}$ First, with respect to the abuse of psychotropic medications, there are significant risks to the patient including misdiagnosis and misadministration. There are even questions as to the extent to which psychotropic medications actually help the patient, even where the patient has been correctly diagnosed. ${ }^{60}$ There is also evidence that psychotropic medications are often used to sedate patients to make them more manageable, ${ }^{61}$ to punish them, ${ }^{62}$ or for administrative convenience, ${ }^{63}$ rather than to afford any real therapeutic benefit. ${ }^{64}$ This is especially true in in-patient facilities, due to overpopulation and insufficient staffing. ${ }^{65}$

Secondly, patient autonomy advocates argue that many persons with mental disabilities are in fact able to make rational decisions regarding their treatment, and psychiatrists and other medical professionals should listen to and respect their opinions. Many patients with psychiatric diagnoses are no less competent than other medical patients to make these types of decisions regarding their treatment. ${ }^{66}$ In cases where a patient has made known their desire to refuse treatment, if the medical professional still believes that the recommended treatment is necessary after considering the patient's concerns, there should be a forum available to that patient, such as an administrative review process or formal court proceeding, to resolve the issue in the best possible manner for the patient. ${ }^{67}$

The acknowledgement of the right to refuse treatment is a way to include the patient in the decision-making process. ${ }^{68}$ Additionally, research shows giving individuals the right to refuse treatment can have therapeutic benefits. ${ }^{69}$ Including the patient in the decision-making process may provide the patient a feeling of inclusiveness, which can in turn have a positive impact on the patient's future behavior and help initiate healing. ${ }^{70}$ Other systemic benefits include providing checks on doctors and staff in clinical settings, ensuring medication is not used as a tool for punishment or convenience for staff, ensuring due process rights for persons with mental disabilities, and providing an extra layer of protection against the administration of inappropriate medications that could potentially cause severe side effects. ${ }^{71}$

59 See generally Winick, supra note 13.

60 Perlin, Mental Disability Law, supra note 9, at $\S 3 \mathrm{~B}-2$.

${ }^{61}$ Heavy medication is sometimes used as "chemical restraints" to calm patients in situations where there is limited staff to monitor patients. Rosenthal \& Ahern, Serbia's Segregation, supra note 39, at 12; Amnesty Int'l, Bulgaria: Failings in the Provision of Care 6 (2005).

62 Oliver Lewis, Mental Disability Law in Central and Eastern Europe: Paper, Practice, Promise, 8 J. Mental Health L. 293, 299 (2002) [hereinafter Lewis, Paper, Practice, Promise].

63 "There is great potential for the abuse of psychotropic medication, and careful scrutiny is required when they are involuntarily administered." Rennie, 462 F. Supp. 1131, 1142 (D.N.J. 1978).

${ }^{64}$ See Cochran v. Dysart, 965 F.2d 649, 650 (8th Cir. 1992) (describing psychotropic medication as an "alternative" to "straightjackets" and "frontal lobotomies"); United States v. Watson, 893 F.2d 970, 978 (8th Cir. 1990) (same), vacated by United States v. Holmes, 900 F.2d 1322 (8th Cir. 1990); In re Guardianship of Roe, 421 N.E.2d 40, 60 (Mass. 1981) (stating that when the safety of others is part of the justification for involuntary medication, "antipsychotic drugs function as chemical restraints").

65 See e.g., Symposium, supra note 42, at 367-368.

66 See The MacArthur Treatment Competence Study: I. Mental Illness and Competence to Consent to Treatment (1995) 19 Law \& Human Behav. 105; see generally Elyn R. Saks \& Stephen H. Behnke, Competency to Decide on Treatment and Research: MacArthur and Beyond, 10 J. CONTEMP. Legal Issues 103 (1999).

${ }^{67}$ See e.g., Rennie v. Klein, 720 F.2d 266 (3rd Cir. 1983) (holding that an involuntarily committed psychiatric patient has a constitutional right to refuse antipsychotic drugs). See also, e.g., Rogers v. Okin, 738 F.2d 1, (1st Cir. 1984) (approving on due process grounds, less protective state procedures for the forcible medication of involuntarily committed patients with mental disabilities).

${ }^{68}$ See Amy D. Ronner, Songs of Validation, Voice, and Voluntary Participation: Therapeutic Jurisprudence, Miranda and Juveniles, 71 U. CIN. L. REv. 89, 94-95 (2002) (discussing the positive impact of allowing litigants to play an active role in their treatment and commitment hearings).

${ }^{69}$ Michael L. Perlin et al., Therapeutic Jurisprudence and the Civil Rights of Institutionalized Mentally Disabled Persons: Hopeless Oxymoron or Path to Redemption?, 1 Psychol. Pub. Pol'y \& L. 80, 110 (1995) [hereinafter Perlin et al., Therapeutic Jurisprudence].

${ }^{70}$ See Ronner, supra note 68, at 94-95.

${ }^{71}$ Id. at $111-116$. 
I argue that the right to receive treatment and the right to refuse treatment can comfortably coexist. This is based on the concept that meaningful, ameliorative individualized treatment is available to an individual at a facility in which he has been committed, and that the treatment is logically geared toward improving the individual's condition so that he can ideally be released. ${ }^{72}$

\section{Therapeutic Jurisprudence}

A discussion of the right to refuse treatment would not be complete without mentioning therapeutic jurisprudence, or the study of how legal systems affect the emotions, behaviors, and mental health of people. ${ }^{73}$

\section{The Value of Therapeutic Jurisprudence}

Therapeutic jurisprudence is centered around a commitment to dignity. ${ }^{74}$ It presents a new model for assessing the impact of case law and legislation, and recognizes that the law can have therapeutic or anti-therapeutic consequences as a therapeutic agent. ${ }^{75}$ The concept of therapeutic jurisprudence is vital to the study of law and human rights because it "asks us to look at law as it actually impacts people's lives"76 by focusing on how the law influences the emotional life and psychological well-being of people in the judicial system. ${ }^{77}$ It is also part of a growing comprehensive movement in the legal field toward handling legal issues in a more humane and psychologically optimal way while focusing on collaboration, creativity, and respect among lawyers and clients with mental disabilities. ${ }^{78}$

There is a strong therapeutic jurisprudence argument for protecting the right to refuse treatment for individuals with mental disabilities. ${ }^{79}$ Studies show that in cases of judicial review, there are therapeutic jurisprudence benefits in that participation in judicial decisions provides people with mental disabilities opportunities to present their case in a more formal legal setting. ${ }^{80}$ Professor Ronner's " 3 Vs" argument states:

Litigants must have a sense of Voice or a chance to tell their story to a decision maker. If that litigant feels that the tribunal has genuinely listened to, heard, and taken seriously the litigant's story, the litigant feels a sense of Validation. When litigants emerge from a legal proceeding with a sense of Voice and Validation, they are more at peace with the outcome. Voice and Validation create a sense of Voluntary participation, one in which the litigant experiences the proceeding as less coercive. Specifically, the feeling on the part of litigants that they Voluntarily partook in the very process that engendered the end result or the very judicial pronunciation that affects their own lives can initiate healing and bring about improved behavior in the

${ }^{72}$ See generally, Wyatt v. Stickney, 344 F. Supp. 373 (M.D. Ala. 1972); see also Perlin, Mental Disability Law, supra note 9, at § 3A-3.1 (characterizing Wyatt as "one of the most influential mental disability law cases ever filed").

${ }^{73}$ See generally David B. Wexler, International Network on Therapeutic Jurisprudence, http://www.law.arizona.edu/depts/ upr-intj/ (last visited April 16, 2016).

74 See Bruce J. Winick, Civil Commitment: A Therapeutic Jurisprudence Model 161 (2005).

${ }^{75}$ See Michael L. Perlin, "His Brain Has Been Mismanaged with Great Skill”: How Will Jurors Respond to Neuroimaging Testimony in Insanity Defense Cases?, 42 Akron L. Rev. 885, 912 (2009); see also, Kate Diesfeld \& Ian Freckelton, Mental Health Law and Therapeutic Jurisprudence, in Disputes and Dilemmas in Health Law 91 (Ian Freckelton \& Kate Peterson eds., 2006) (providing a transnational perspective).

${ }^{76}$ Bruce J. Winick, Foreword: Therapeutic Jurisprudence Perspectives on Dealing with Victims of Crime, 33 Nova L. REv. 535,535 (2009).

${ }^{77}$ David B. Wexler, Practicing Therapeutic Jurisprudence: Psychological Soft Spots and Strategies, in DANIEL P. Stolle, David B. Wexler, \& Bruce J. Winick, Practicing Therapeutic Jurisprudence: Law as a Helping Profession 45 (2006).

${ }^{78}$ Susan Daicoff, The Role of Therapeutic Jurisprudence Within the Comprehensive Law Movement, in Daniel P. STOLLE, David B. Wexler, \& Bruce J. Winick, Practicing Therapeutic Jurisprudence: Law as a Helping Profession 45, 365 (2006).

${ }^{79}$ Perlin et al., Therapeutic Jurisprudence, supra note 69, at 110.

${ }^{80}$ See Francine Cournos et al., A Comparison of Clinical and Judicial Procedures for Reviewing Requests for Involuntary Medication in New York, 39 Hosp. \& Community Psychiatry 851, 854 (1988); see also, Paul Sauvayre, The Relationship Between the Court and the Doctor on the Issue of an Inpatient's Refusal of Psychotropic Medication, 36 J. Forensic SCI. 219, 221 (1991) (citing Irwin Hasenfeld and Barbara Grumet, A Study of the Right to Refuse Treatment, 12 Bull. Am. ACAD. Psychiatry \& L. 65 (1984) (patients who originally refuse treatment and complete a judicial hearing as to their capacity to refuse treatment did better following discharge than those who comply with treatment in the first place). 
future. In general, human beings prosper when they feel that they are making, or at least participating in, their own decisions. ${ }^{81}$

Ensuring people with mental disabilities receive due process provides, at a very minimum, the appearance of fairness. This is therapeutic because it contributes to the individual's sense of dignity and conveys that he or she is being taken seriously. ${ }^{82}$

\section{The Importance of Effective Counsel in Addition to Therapeutic Jurisprudence}

Advancing the prevalence of therapeutic jurisprudence for people with mental disabilities alone isn't enough. The right to effective counsel is also imperative to ensure that the rights of persons with mental disabilities are more than mere "paper victories," but that their rights, including the right to refuse treatment, are actually protected. ${ }^{83}$ In their article, Voiceless Billy Budd: Melville's Tribute to the Sixth Amendment, Professor Amy Ronner and Judge Juan Ramirez recognize the right to effective counsel as "the core of therapeutic jurisprudence," 84 and suggest that the attorney is essential in the legal context for the mentally disabled, especially in criminal proceedings. The attorney assists individuals in articulating their wishes and telling their stories, and aids in effectuating the individuals' participatory interests, thus giving them a voice and validation. ${ }^{85}$

In practice, lawyers are generally held to the standard of "reasonable competence." They have a duty to keep up to date on changes in the law and are charged with being vigorous advocates for their clients. When representing a client with a mental disability or dealing with an involuntary civil commitment hearing, a lawyer naturally faces heightened obligations in providing effective counsel. At a minimum, counsel should have a "competent understanding of the legal process of involuntary commitments as well as fair knowledge of the range of alternative, less restrictive treatment and care options available." 86 Counsel should fully investigate and comprehend the patient's circumstances prior to an involuntary civil commitment hearing or trial. ${ }^{87}$ To be effective, this requires extensive work with the client to understand the client's needs and options. ${ }^{88}$ Therefore, counsel must wear two hats throughout the representation and act as both an advocate and an adversary. ${ }^{89}$

${ }^{81}$ Ronner, supra note 68 , at 94-95.

${ }^{82}$ See John Ensimger \& Thomas Liguori, The Role of Counsel in the Civil Commitment Process; A Theoretical Framework, in Theoretical Jurisprudence: The Law as a Therapeutic Agent (David Wexler ed. 1 1990) 309, 323 n. 83; see also, Tom R. Tyler, The Psychological Consequences of Judicial Procedures: Implications For Civil Commitment Hearings, 46 SMU L. REv. 433, 444 (1992) (discussing the therapeutic value of judicial civil commitment hearings, and emphasizing that individuals benefit from hearings in which they are able to take part, are treated with dignity, and are "fair"); see also, Amy D. Ronner, Punishment Meted Out for Acquittals: An Anti-therapeutic Jurisprudence Atrocity, 41 ArIz. L. Rev. 459, 472-477 (1999) (discussing how unfair procedures lead to disrespect for the law, disregard for human life, rage, and a sense of helplessness).

${ }^{83}$ See Michael L. Perlin, "What's Good is Bad, What's Bad is Good, You'll Find Out When You Reach the Top, You're on the Bottom": Are the Americans with Disabilities Act (and Olmstead v. L.C.) Anything More Than "Idiot Wind?", 35 U. Mich. J.L. Reform 235, 246 (2002) [hereinafter Perlin, What's Good is Bad] ("Mental disability law is strewn with examples of 'paper victories." (quoting Michael Lottman, Paper Victories and Hard Realities in PaPer Victories and Hard Realities: The Implementation of the Legal and Constitutional Rights of the Mentally Disabled 93 (Valerie J. Bradley \& Gary J. Clarke eds., 1976))).

${ }^{84}$ Juan Ramirez, Jr. \& Amy D. Ronner, Voiceless Billy Budd: Melville's Tribute to the Sixth Amendment, 41 CAL. W. L. REV. 103, 119 (2004).

${ }^{85}$ See Amy D. Ronner \& Bruce J. Winick, Silencing the Appellant's Voice: The Anti-therapeutic Per Curiam Affirmance, 24 Seattle U. L. Rev. 499, 503-504 (2000); see also generally, Michael L. Perlin \& Deborah A. Dorfman, "Is it More than Dodging Lions and Wastin' Time?" Adequacy of Counsel, Questions of Competence, and the Judicial Process in Individual Right to Refuse Treatment Cases, 2 Psychology Pub. Pol'y \& L. 114 (1996) [hereinafter Perlin \& Dorfman, Dodging Lions].

${ }^{86}$ In re Mental Health of K.G.F., 29 P.3d 485, 498, 2001 MT 140.

${ }^{87} I d$. at 492.

${ }^{88} \mathrm{Id}$. at 498 .

${ }^{89} \mathrm{Id}$. at 500 . 


\section{The Need for Protection for People with Mental Disabilities in Institutions}

I am focusing this article on persons with mental disabilities who are in institutions because they are more prone to become victims of abuse and coercion than people with mental disabilities who are not institutionalized. ${ }^{90}$ Thus, "treatment," for the purposes of this article, is limited to in-patient psychiatric treatment, meaning patients who are committed to institutions for mental disabilities. This includes both voluntary and involuntary civil commitment. "Voluntary commitment" is where a patient willingly admits him or herself into an institution, while "involuntary civil commitment" is the admission of individuals against their will into a mental health unit. Typically, in order to involuntarily commit or treat an individual without his or her prior consent it must be shown that the individual is "a danger to him or her self" or "a danger to others." 91 In general, there are three reasons why an individual would be subject to involuntary civil commitment: (1) mental illness, (2) developmental disability, or (3) substance addiction. $^{92}$

\section{Inadequate Facilities and Unhealthy Living Conditions}

Forced treatment, as discussed above can take on various forms, and can even rise to the level of intrusion on fundamental human rights. But it is also important to recognize that detention in a mental health facility, in and of itself, may also be a violation of an individual's fundamental rights to privacy liberty, and due process. ${ }^{93}$ This is due to the fact that a vast majority of psychiatric institutions are state-owned and all too often the State fails to live up to its obligations to provide individuals in its custody with adequate food, water, medical care, and clothing, the absence of which may ultimately constitute torture and ill-treatment. 94

Many persons with mental disabilities live in horrible conditions in large, segregated institutions and are subject to various forms of abuse. Practices that would otherwise be deemed torture are justified on medical and economic grounds. Persons with mental disabilities face chemical and physical restraints, "corrective" medical interventions, physical and sexual violence, and often are forced to live in facilities that are not adapted to their needs. ${ }^{95}$

Contrary to popular belief, locking up and forcibly medicating people with mental disabilities is not in their best interests nor is it in the best interest of society as a whole. A strong argument can be made that, rather than protecting public safety, this theory actually decreases public safety. And instead of helping psychiatric patients, in reality, many are greatly harmed. ${ }^{96}$ Instead of seeking meaningful treatment and steps toward inclusion into society, this method secludes people with mental disabilities in addition to denying individuals their right to freedom and the right to decline psychiatric treatment. This methodology also fails to recognize that many people

90 See Anna Lawson, Disability, Degradation and Dignity: The Role of Article 3 of the European Convention on Human Rights, 56 N. IR. LEgAL Q. 462, 476 (commenting on the disturbing conditions found in a number of institutions in the United Kingdom, "which appear to reflect a complete absence of concern for the dignity and well-being of residents"); see also, Anna Lawson, The United Nations Convention on the Rights of Persons with Disabilities: New Era or False Dawn?, 34 SyRAcuse J. INT'L L. \& CoM. 563, 570 (2007) (noting the "shocking conditions of a residential home for disabled people in Cornwall" in the United Kingdom); see also, Mental Disability Rights International, Torture Not Treatment: Electric Shock and LongTerm Restraint in the United States on Children and Adults with Disabilities at the Judge Rotenberg Center (2010) (documenting human rights abuses of children and young adults with mental disabilities at the Judge Rotenberg Center in Canton, Massachusetts); see also Human Rights Watch Report, supra note 36 (and accompanying text).

${ }^{91}$ Ralph Reisner, Christopher Slobogin, \& Arti Rai, Law and the Mental Health System: Civil and Criminal Aspects 704-705 (5th ed. 2009) (discussing the civil commitment standard in the United States); see also MI Principles supra note 10, at Principle 11(6) (listing dangerousness to self or others as an exception to when informed consent is required to treat an individual with a mental disability in the internationally recognized Principles for the Protection of Persons with Mental Illness and the Improvement of Mental Health Care ("MI Principles"); see also e.g., The Mental Health Bill, 2014, available at http://www.kenyalaw.org (last visited April 16, 2016) (outlining that emergency treatment of persons with mental disabilities is statutorily permitted in Kenya only if the individual is an "immediate" and "imminent" danger to himself or others).

92 See REISNER ET AL., supra note 91, at 704-705.

93 See generally the Nowak Interim Report on Torture, supra note 5.

94 See generally id; see also, Ximenes-Lopes v. Brazil, Inter-Am. Ct. H.R. (ser. C) No. 139, ๆ 132, 150 (July 2006).

${ }^{95}$ Fiala-Butora, supra note 6, at 216.

96 Gottstein, supra note 8, at 51. 
with mental disabilities are quite capable of living in society and of making their own informed decisions regarding treatment and therapy.

Historically, the European Court of Human Rights (ECtHR) has been deferential to forced medication provided particular procedural standards are met and doctors are involved in the decision-making process. ${ }^{97}$ However, more recently, the ECtHR has recognized that poor conditions of confinement can constitute inhuman or degrading treatment. For example, in Stanev v. Bulgaria ${ }^{98}$ (2012), Mr. Stanev, a patient diagnosed with schizophrenia, was improperly detained for seven years by his guardian (without a court hearing) in a dilapidated facility that lacked adequate food, running water, access to toilets, privacy, or almost any form of meaningful activity. ${ }^{99}$ The ECtHR found that these conditions amounted to "degrading" treatment and thus violated Article 3 of the European Convention on Human Rights (ECHR). ${ }^{100}$ The Court further found that his long-term detainment in the facility without a court hearing constituted deprivation of liberty. ${ }^{101}$ Stanev is a significant case because it is the first case in which the ECtHR found a violation of Article 3 of the ECHR, which calls for an absolute prohibition on torture, inhuman or degrading treatment, or punishment in an institution for people with disabilities. ${ }^{102}$

\section{Abuse and Misuse of Medications and Treatments}

In many countries, people with psychosocial disabilities can be legally administered medication without their consent. For example, patients who pose a danger to themselves or others around them are rarely given the opportunity to refuse treatment. ${ }^{103}$ Additionally, patients who have clearly demonstrated a lack of capacity to give proper consent are seldom informed of the type or affects of treatment administered, let alone given the opportunity to refuse such treatment. ${ }^{104}$ These omissions are clearly violations of internationally recognized principles under the United Nations Convention on the Rights of Persons with Disabilities (CRPD) discussed more fully below in section III(A). ${ }^{105}$

One argument in support of the right to refuse treatment is the potential for abuse and misuse. All too often medications, restraints, and other forms of treatment are used to sedate or punish patients rather than to actually treat their symptoms. Even if treatment is administered with good intentions, it often leaves a powerful, sometimes lasting effect on the patient. For example, psychotropic medications are known to "affect the mind, intellectual functions, perception, moods, and emotions." 106

Social scientists and courts have recognized that the misuse of psychotropic medication, such as for submission, control, or unnecessary sedation rather than for healing or treatment purposes, is a concern in that medication

97 See e.g., Winterwerp v. Netherlands, App. No. 6301/73, 2 Eur. H.R. Rep. 387, 404-407 (Oct., 1979) (finding there was no Article 5 violation of the European Convention on Human Rights where the decision to compel treatment was based on doctors' medical reports and there were no violations of minimal procedural guarantees under the domestic law).

98 Stanev v. Bulgaria, App. No. 36760/06, Eur. Ct. H.R., 46 (Jan., 2012).

99 Id. at $110,20-23$.

${ }^{100} I d$. at 9 204, 209, 210, 213; see also Y.B. Eur. Conv. on H.R. [hereinafter ECHR].

101 Id. at 117,118 .

102 Oliver Lewis, Stanev v. Bulgaria: On the Pathway to Freedom, 19 Human Rights Brief 2, Art. 1, 1, 3 (2012); see also ECHR, supra note 100, at Article 3.

103 The Nowak Interim Report on Torture, supra note 5.

104 See e.g., Documentary: Forgotten People (Sproutflix 2000), available at http://sproutflix.org/all-films/forgotten-people/ (last visited April 16, 2016) (documenting the inhuman living conditions and forced treatment of people with mental disabilities all over the world.)

105 See generally the Nowak Interim Report on Torture, supra note 5. "Whereas a fully justified medical treatment may lead to severe pain or suffering, medical treatments of an intrusive and irreversible nature, when they lack a therapeutic purpose, or aim at correcting or alleviating a disability, may constitute torture and ill-treatment if enforced or administered without the free and informed consent of the person concerned." Id. at 11 .

${ }^{106}$ Myers v. Alaska Psychiatric Inst., 138 P.3d 238, 241, (Alaska 2006) (citing Steele v. Hamilton County Cmty. Mental Health Bd., 90 Ohio St. 3d 176, 736 N.E.2d 10, 15 n.3 (Ohio 2000)); see also V. Longo, Neuropharmacology And Behavior 182 (1972); Gerald L. Klerman, Psychotropic Drugs as Therapeutic Agents, 2 Hastings Center Stud. 81,82 n.1. (Jan. 1974). 
decisions made by someone other than an independent party could lead to such misuse. ${ }^{107}$ Research has shown that a right to refuse treatment accompanied by due process proceedings are effective in preventing misuse. ${ }^{108}$

Additionally, due to their inability to leave the facility, patients in psychiatric institutions are especially susceptible to the use of experimental treatments with the purpose of correcting and alleviating particular ailments or disabilities, including sterilization and/or abortion, ECT, and mind-altering medications. These treatments can be intrusive and irreversible and are often administered without consent. ${ }^{109}$ The fact that some practices (such as unmodified ECT) are still used in some nations, while other nations have completely outlawed the same practices, reminds us of "the gap between the formal equality of persons with [mental] disabilities and the reality, which is governed by 'exceptions' and medical rules." 110

All of the above illustrations demonstrate why international law and conventions such as the CRPD are of vital importance to promoting, protecting, and enforcing the rights of people with mental disabilities.

Under international human rights law, while States have the primary responsibility for the protection of rights, it is the international community that bears the subsidiary responsibility of protection in areas where national institutions present failures or omissions in the protection of rights. ${ }^{111}$ The main objective of these international safeguards is to peremptorily provoke advances in the national human rights protection systems. ${ }^{112}$

\section{InTERnational Documents}

\section{A. Convention on the Rights of Persons with Disabilities (CRPD), 2006}

The Convention on the Rights of Persons with Disabilities (CRPD) ${ }^{113}$ is an international human rights treaty adopted by the United Nations General Assembly on December 13, 2006. ${ }^{114}$ It opened for signatures on March 30, 2007, and came into force on May 3, 2008, after ratification by the 20th State Party. ${ }^{115}$ The CRPD has been signed by 160 States and has been ratified, accessed, or confirmed by 161 State Parties. ${ }^{116}$ The CRPD was the first human rights treaty to be ratified by a regional integration organization, the European Union. ${ }^{117}$

${ }^{107}$ Perlin et al., Therapeutic Jurisprudence, supra note 69, at 114 (citing Washington v. Harper, 494 U.S. $210,242-243$ (1990) (Stevens, J. dissenting), Riggins, supra note 27 at 139 (Kennedy, J., concurring), Heller v. Doe, 509 U.S. 312,335 (1993) (Souter, J., dissenting)). In Washington v. Harper, Justice Stevens expressed his concerns that the failure to require that medication decisions be made by an independent party could lead to the improper use of medication for control purposes rather than for treatment. Harper, infra note 107, at 245-246; see also, e.g., Rennie v. Klein, 476 F. Supp. 1294, 1299 (D.N.J. 1979) (evidence at trial indicated that psychiatric medications were being used routinely as a means of patient control and as a substitute for treatment), modified and remanded, 653 F.2d 836 (3rd Cir. 1981), vacated and remanded, 458 U.S. 1119 (1982).

${ }^{108}$ Perlin et al., Therapeutic Jurisprudence, supra note 69, at 114 (citing Davis v. Hubbard, 506 F. Supp. 915, $926-927$ (N. D. Ohio 1980); Mary C. McCarron, The Right to Refuse Antipsychotic Drugs: Safeguarding the Mentally Incompetent Patient's Right to Procedural Due Process, 73 Maro. L. Rev. 477, 484 (1990)).

109 The Nowak Interim Report on Torture, supra note 5, at 13-14.

110 Fiala-Butora, supra note 6, at 238-239.

111 Cassia Maria Rosato \& Ludmila Cerqueira Correia, The Damiao Zimenes Lopes Case: Changes and Challenges Following the First Ruling Against Brazil in the Inter-American Court of Human Rights, 15 INT'L J. ON HuM. RTs. 91 , 94 (2011).

112 Id. at 94.

113 CRPD, supra note 12.

${ }^{114}$ United Nations Human Rights, Office of the High Commissioner for Human Rights, Convention on the Rights of Persons with Disabilities, Questions and answers, http://www.ohchr.org/EN/HRBodies/CRPD/Pages/QuestionsAnswers.aspx (last visited April 16, 2016).

${ }^{115} \mathrm{Id}$

${ }^{116}$ United Nations Treaty Collection, https://treaties.un.org/Pages/ViewDetails.aspx?src=IND\&mtdsg_no=IV-15\&chapter $=4 \&$ lang=en. (last visited April 16, 2016). Ratification means the State consents to be bound and follows a signature to the agreement. Accession has the same legal effect as ratification but does not require signing. Confirmation also entails consent to be bound and requires that the treaty is signed by the Head of State, Head of Government or Minister of Foreign Affairs. United Nations, Ask DAG: What is the Difference Between Signing, Ratification and Accession of UN Treaties?, available at http://ask.un.org/faq/14594 (last visited April 16, 2016) [hereinafter United Nations, Ask DAG].

117 See generally CRPD, supra note 12. 
The United States, Brazil, and Kenya have all signed the CRPD. The United States signed in July of 2009, but has yet to ratify it, ${ }^{118}$ thus making it a non-binding authority in the United States. ${ }^{119}$ Brazil signed in March of 2007 and ratified it in August 2008. ${ }^{120}$ Kenya signed in March of 2007 and ratified it in May 2008. ${ }^{121}$

\section{The CRPD and Persons with Mental Disabilities}

The CRPD is an international human rights treaty that speaks specifically about persons with disabilities. It is all-inclusive meaning that it addresses those persons with both physical and mental disabilities. It adopts a broad categorization of persons with disabilities and reaffirms that all persons, with all types of disabilities, must enjoy all human rights and fundamental freedoms. It is also the only international convention on the rights of persons with disabilities that is legally binding and enforceable ${ }^{122}$ (also known as "hard law"). Other international documents, such as the UN Principles for the Protection of Persons with Mental Illness and for the Improvement of Mental Health Care, discussed below in section B(4), and the Declaration on the Rights of Mentally Retarded Persons, discussed in section $\mathrm{B}(2)$, are soft law, and thus not legally binding or enforceable. ${ }^{123}$

Before the CRPD, the only hard law documents on the issue of human rights and disabilities were the International Covenant on Civil and Political Rights, discussed in section $\mathrm{B}(1)$, and the International Covenant on Economic, Social and Cultural Rights. Unfortunately, these do not deal specifically with disabilities. Nothing before the CRPD was international hard law specifically targeted to persons with disabilities. ${ }^{124}$ As such, Professor Perlin refers to the CRPD as "the most comprehensive document on international disability law ever created." 125

\section{The CRPD and the Right to Refuse Treatment: Articles 14, 15, and 25}

Relevant articles of the CRPD that speak to the right to refuse treatment include Article 14 (Liberty and security of the person), Article 15 (Freedom from torture or cruel, inhumane or degrading treatment or punishment), and Article 25 (Health).

Article 14 explicitly addresses liberty and security of the person. ${ }^{126}$ It provides that people with disabilities shall have the right to liberty and security of person, on an equal basis with others, and that individuals shall not be deprived of these rights unlawfully or arbitrarily. ${ }^{127}$ It further states that the mere existence of a disability is not justification for deprivation of liberty. ${ }^{128}$ It goes on to provide remedies and enforcement measures declaring that if an

118 United Nations Human Rights, Office of the High Commissioner for Human Rights, Reporting Status for the United States of America, available at http://tbinternet.ohchr.org/_layouts/TreatyBodyExternal/Countries.aspx?CountryCode= USA\&Lang=EN (last visited April 16, 2016).

${ }^{119}$ Simply signing a treaty imposes no legal obligation on a member state. Rather it is an intention to be bound by the treaty at a later date. However, signing does create an obligation to refrain from acts that would defeat the object and purpose of the treaty. United Nations, Ask DAG, supra note 116. A state becomes legally bound by a treaty at the international level upon ratification of the treaty. $I d$.

${ }^{120}$ United Nations Treaty Collection, supra note 116.

${ }^{121} \mathrm{Id}$

122 Id.

${ }^{123}$ On the significance of soft law in the development of international human rights, see Christian Courtis, Disability Rights in Latin America and International Cooperation, 9 S.w. J.L. \& TRADE AM. 109 (2002-2003); Soft law may guide the interpretation, elaboration, or application of hard law; constitute norms that aspire to harden; serve as evidence of hard law; exist in parallel with hard law obligations and act as a fall-back; or serve as a source of relatively hard obligations through acquiescence or estoppel. See Jose Alvarez, The New Dispute Settlers: (Half) Truths and Consequences, 38 TeX. INT'L L.J. 405,421 (2003).

${ }^{124}$ Eva Szeli, PhD, JD, Adjunct Professor of Law, New York Law School, Psychology Faculty, Arizona State University, Class Lecture: International Human Rights - Part II: United Nations, at New York Law School (March 3, 2014), available at, http://nyls.mediasite.com/mediasite/Play/4f99717b155f4b26b9a5cfa5bf0bb89b1d?catalog=09b3d409-d7b9-470c-bfae-8b3e2e a43e27 (last visited April 16, 2016).

125 Michael L. Perlin, "Striking for the Guardians and Protectors of the Mind": The Convention on the Rights of Persons with Mental Disabilities and the Future of Guardianship Law, 117 Penn St. L. Rev. 1159 (2013).

${ }^{126}$ CRPD, supra note 12, at Article 14.

${ }^{127} \mathrm{Id}$.

${ }^{128}$ Id. at Article 14(1)(b). 
individual is deprived of liberty, States Parties have a duty to ensure that individuals are entitled to guarantees in accordance with international human rights law. ${ }^{129}$ This Article could be interpreted broadly to include the right to refuse treatment in terms of liberty of the person.

Article 15 discusses freedom from torture or cruel, inhumane or degrading treatment or punishment, ${ }^{130}$ and provides that no one shall be subjected to medical or scientific experimentation without his or her free consent and that States Parties shall take all effective legislative, administrative, judicial, or other measures to prevent persons with disabilities from being subjected to torture or cruel, inhuman or degrading punishment or treatment. ${ }^{131}$

Article 25 requires health care professionals provide the same care to persons with disabilities as any other person in a variety of ways. ${ }^{132}$ Specifically, it provides that States Parties have a duty to provide people with disabilities with:

1. the same range, quality, and standard of free or affordable health care;

2. the specific health care services needed due to their disability;

3. health care services as close in proximity as possible to communities, including rural communities;

4. the same standard of quality of care as others including requiring informed consent, and raising awareness of human rights, dignity, autonomy, and needs of persons with disabilities;

5. protection from discrimination against persons with disabilities with regard to health insurance and life insurance; and

6. protection from discrimination in the denial of health services, food, and fluids based on disability. ${ }^{133}$

\section{The CRPD and Access to Adequate and Dedicated Counsel: Article 13}

Access to adequate and dedicated counsel is one of the most critical issues in bringing life to international human rights law within a mental disability law context. ${ }^{134}$ In many nations, mental health laws are non-existent, thus illustrating how those States' legislative bodies have completely failed to address the needs of people with mental disabilities. ${ }^{135}$ Even worse, other countries lack provisions providing legal counsel altogether at an adjudication or civil commitment proceeding - regardless of the defendant's mental health. ${ }^{136}$ Still other countries have what is referred to as the "warm body" problem, in which legal counsel appears to be present in name only. ${ }^{137}$

The CRPD mandates that "States Parties shall take appropriate measures to provide access by persons with disabilities to the support they may require in exercising their legal capacity." 138 The CRPD further provides:

States Parties shall ensure effective access to justice for persons with disabilities on an equal basis with others, including through the provision of procedural and age appropriate accommodations, in order to facilitate their effective role as direct and indirect participants, including as witnesses, in all legal proceedings, including at investigative and other preliminary stages. ${ }^{139}$

Availability of adequate counsel is so important to protect the rights of all people with mental disabilities because without it, it would be "virtually impossible to imagine the existence of the bodies of involuntary civil

${ }^{129}$ Id. at Article 14(2).

${ }^{130}$ Id. at Article 15.

${ }^{131} \mathrm{Id}$.

${ }^{132} I d$. at Article 25.

${ }^{133} I d$.

134 See Perlin, The Universal Factors, supra note 38, at 342; see also, Oliver Lewis, Protecting the Rights of People with Mental Disabilities: The European Convention on Human Rights, 9 Eur. J. Health L. 293, 316 (2002).

135 See Perlin \& Schriver, supra note 45, at 337-40 (listing multiple examples).

136 Id. at 340-42 (same).

137 See e.g., Pamela Metzger, Doing Katrina Time, 81 Tul. L. REv. 1175, 1198 (2007) (“This right to counsel is not satisfied by the mere appearance of a warm body wearing a business suit and holding a copy of the [statute book].").

${ }^{138}$ CRPD, supra note 12, at Article 12.

${ }^{139}$ Id. at Article 13. 
commitment law, [the] right to treatment law, [the] right to refuse treatment law, or any aspect of forensic mental disability law that are now taken for granted."140

\section{B. Other UN Documents}

Prior to the CRPD, there were international instruments that spoke to substantive protections for persons with mental disabilities, however these instruments did not contain the enforcement mechanisms that are present in the CRPD. ${ }^{141}$ These other documents are discussed below.

\section{The International Covenant on Civil and Political Rights, 1976 ("ICCPR")}

The International Covenant on Civil and Political Rights (“ICCPR"), ${ }^{142}$ part of the International Bill of Human Rights, is a United Nations treaty that came into force in 1976. It ensures the basic human rights principles of dignity and autonomy, as well as the right to be recognized as a person before the law. ${ }^{143}$ It also allows people to make individual life choices such as personal and religious beliefs on the basis of their conscience. ${ }^{144}$

Other rights, such as the right to privacy (Article 17), and the right to freedom of thought, conscience, and religion (Article 18), are also relevant in ensuring the effective enjoyment of the right to decide autonomously about one's life. ${ }^{145}$

Article 7 of the ICCPR ensures protection from torture or other forms of inhuman or degrading treatment and provides that no one shall be subjected to medical or scientific experimentation. ${ }^{146}$ While Article 9 provides that persons have the right not to be arbitrarily arrested or detained, it also sets out the basic human rights standards with regard to treatment in mental health facilities. Treatment must be directed towards preserving and enhancing the personal autonomy of the patient, and be provided in accordance with applicable standards of ethics for mental health practitioners, including internationally accepted standards. ${ }^{147}$ Patients have the right to be treated with the least restrictive or intrusive treatment, and on the basis of an individually prescribed plan, discussed with the patient and reviewed regularly by qualified professional staff. ${ }^{148}$

Finally, Article 14 provides that all persons shall have equal rights before the courts. ${ }^{149}$ This encourages liberty and freedom, but does not establish standards for when persons with mental disabilities can be committed or treated against their will.

\section{The Declaration on the Rights of Mentally Retarded Persons, 1971 (The MR Declaration)}

The Declaration on the Rights of Mentally Retarded Persons ${ }^{150}$ (the "MR Declaration") was adopted by the General Assembly in 1971. Despite its outdated use of the term "mental retardation," it was the first formal recognition of people with mental disabilities by the international community. ${ }^{151}$ It provides that whenever possible, the "mentally retarded" person should live with his family or foster parents and participate in community life. ${ }^{152}$ If an institution is necessary, it should be provided in surroundings and other circumstances as close to normal life as

${ }^{140}$ Michael L. Perlin, International Human Rights and Mental Disability Law: When the Silenced Are Heard, 34.

(2012) [hereinafter Perlin, Silenced]

141 Sezli, supra note 124.

142 International Covenant on Civil and Political Rights, Dec. 16, 1966, 999 U.N.T.S. 171[hereinafter ICCPR].

143 See generally Id.

144 See generally Id.

${ }^{145}$ Id. at Article 17, 18.

146 ICCPR, supra note 142, at Article 7.

${ }^{147}$ Id. at Article 9.

${ }^{148} I d$.

${ }^{149}$ Id. at Article 14.

150 G.A. Res. 2856 (XXVI) (Dec. 20, 1971) [hereinafter MR Declaration].

151 See Arlene Kanter, The Development of Disability Rights Under International Law: From Charity to Human Rights 32 (2015).

${ }^{152}$ ICCPR, supra note 142, at Article 4. 
possible. ${ }^{153}$ It further provides persons with mental disabilities have a right to protection from exploitation, abuse, and degrading treatment. ${ }^{154}$ Finally, it guarantees protections and allows for legal safeguards when persons with mental disabilities are not able to exercise their rights in a meaningful way. ${ }^{155}$

\section{The Declaration on the Rights of Disabled Persons, 1975}

The Declaration on the Rights of Disabled Persons, ${ }^{156}$ adopted in 1975, adds additional protections for persons with disabilities. For example, it provides that if a person with a disability needs to be in an institution, the environment and living condition shall be as close as possible to the normal life of a person his or her own age. ${ }^{157}$ It further provides that disabled persons are entitled to measures to become as self-reliant as possible. ${ }^{158}$

Although the MR Declaration and the Declaration on the Rights of Disabled Persons do not specifically address the right to refuse treatment, the rights and protections laid out in these documents can logically be applied to the right to refuse treatment.

\section{Principles for the Protection of Persons with Mental Illness and the Improvement of Mental Health Care, 1991 (The MI Principles)}

In 1991, the Principles for the Protection of Persons with Mental Illness and the Improvement of Mental Health Care 159 (the "MI Principles") established for the first time international due process standards prior to the institutionalization of a mentally disabled person. Significantly, it was the first international document to provide basic minimum standards for treatment of people with mental disabilities in institutional as well as community settings. ${ }^{160}$ The MI Principles set the standard, but they were not enforceable. In 1999, the court in Victor Rosario Congo v. Ecuador ${ }^{161}$ (discussed in greater detail below in section V(A)(5)) enforced the MI Principles, thus solidifying the transition from soft law into hard law.

The MI Principles provide important substantive protections for persons who are involuntary committed including bans on sterilization, psychosurgery, and other types of irreversible treatments, ${ }^{162}$ and also restrict the use of seclusion and physical restraints. ${ }^{163}$ Unfortunately, these restrictions are not absolute. The MI Principles do permit the use of seclusion or restraint when "it is the only means available to prevent immediate harm to the patient or others," and they may not be used longer than the "period it is strictly necessary for this purpose." 164 Fortunately, a personal representative must be given notice of the physical restraint or seclusion of a patient. ${ }^{165}$ Finally, the MI Principles also include specific provisions for conditions and patient rights inside mental health facilities. ${ }^{166}$ For these reasons, the MI Principles were revolutionary in terms of setting the standard for civil commitment for persons with mental disabilities in international law.

Principle 11 provides protection for persons held in institutions against forced or involuntary treatment and guarantees that no treatment shall be given to a patient without his or her informed consent. "Informed consent" is consent obtained freely, without threats or improper inducements, after appropriate disclosure to the

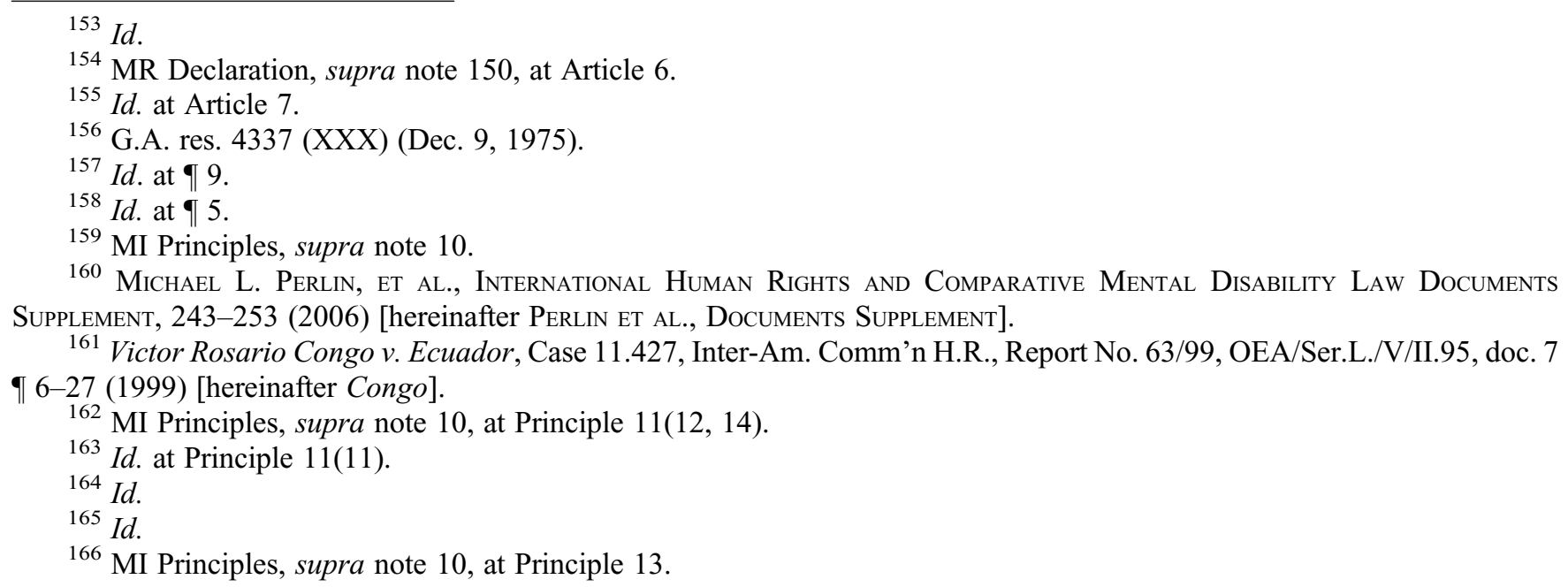


patient. ${ }^{167}$ The disclosure must be adequate and understandable information and in a form and language understood by the patient. ${ }^{168}$ Again, this is not without exceptions. Principle 11 permits involuntary treatment when (1) an independent authority ${ }^{169}$ finds that the individual lacks the capacity to give or withhold informed consent (or unreasonably withholds such consent), ${ }^{170}$ and (2) the proposed plan of treatment is in the best interest of the patient's health needs. ${ }^{171} 172$ With regard to individuals placed under guardianship, Principle 11 requires the guardian be fully informed about the treatment and consent to it on the individual's behalf. ${ }^{173}$

Before the MI Principles, there were very few procedural protections for the right to refuse treatment. While the CRPD is less specific than the MI Principles with regard to the right to refuse treatment, the CRPD has more "teeth" than the MI Principles (which has been severely critiqued in this regard), because the CRPD is a binding international document with enforcement mechanisms. ${ }^{174}$ The CRPD is such an important treaty as it is an international law document that is legally binding and enforceable. ${ }^{175}$

\section{The United Nations Convention against Torture and Other Cruel, Inhuman or Degrading Treatment or Punishment, 1984 (CAT)}

The United Nations Convention against Torture and Other Cruel, Inhuman or Degrading Treatment or Punishment ${ }^{176}$ ("CAT"), adopted in 1984, is another important treaty for the rights of persons with mental disabilities. It was intended to strengthen existing international law prohibitions on torture. ${ }^{177}$ Under CAT, a practice may constitute torture if it is an intentional act by a public official or someone acting in official capacity (or with the consent or acquiescence of a public official) and causes severe mental or physical pain or suffering to another. ${ }^{178}$ Additionally, the "intent to cause pain" requirement can be implied as CAT does not require specific evidence of the motivations of treating professionals. ${ }^{179}$ Further, where a practice does not rise to the level of torture, it may still be prohibited by CAT if it constitutes ill-treatment ("cruel, inhuman or degrading treatment or punishment"). ${ }^{180}$ Finally, merely stating that a practice is therapeutic (as it protects individuals who are institutionalized) may not exclude it from being labeled as torture. ${ }^{181}$ Thus, certain types of coerced treatment or the use of seclusion and restraints are often considered violations of CAT as well as violations of the CRPD and other international human rights treaties. ${ }^{182}$

${ }^{167}$ Id. at Principle $11(1,2)$

168 Id. at Principle 11(2).

169 The MI Principles do not define what an "independent authority" includes nor the scope of its powers. The Principles also do not include any standards that the independent authority must use to reach its determination that the treatment is given without consent. Id. at Principle 11.

${ }^{170}$ MI Principles, supra note 10, at Principle 11(6b).

${ }^{171}$ Id. at Principle $11(6 \mathrm{~b})$.

${ }^{172}$ Id. at Principle 11(6c).

173 Id. at Principle 11(7); see also U.N. Secretary General, Progress of Efforts to Ensure the Full Recognition and Enjoyment of the Human Rights of Persons with Disabilities, U.N. Doc. A/58/181 (Apr. 25, 2002).

174 Szeli, supra note 124; but see also e.g., Tina Minkowitz, The United Nations Convention on the Rights of Persons with Disabilities and the Right to be Free from Nonconsensual Psychiatric Interventions, 34 SyracuSE J. INT'L L. \& COM. 405,407 (2007) (criticizing the MI Principles for not being sufficiently protective of the rights of persons with psychosocial disabilities, especially regarding the right to refuse treatment); T.W. Harding, Human Rights Law in the Field of Mental Health: A Critical Review, 101 Acta Psychiatrica Scandinavica 24, 24 (2000) (discussing how the MI Principles are "basically flawed" and specifically referring to the right to refuse treatment).

175 See generally, Perlin, Mental Disability Law, supra note 9.

176 G.A. Res. 3452 (XXX), The United Nations Convention against Torture and Other Cruel, Inhuman or Degrading Treatment or Punishment (Dec. 10, 1984) [hereinafter CAT].

177 J. Herman Burgers \& Hans Danelius, The United Nations Convention Against Torture: A Handbook on the Convention Against Torture and Other Cruel, Inhuman or Degrading Treatment or Punishment 1 (1988).

${ }^{178}$ CAT, supra note 176 , at Article 1.

179 See generally the Nowak Interim Report on Torture, supra note 5.

${ }^{180}$ CAT, supra note 176, at Article 16; see also Rosenthal \& Ahern, Institutions, supra note 2, at 14.

${ }^{181}$ See the Nowak Interim Report on Torture, supra note 5, at 14,49 (discussing how discrimination and ill treatment of persons with disabilities may be present even if the treatment is "masked as "good intentions" by health care professionals.)

182 Rosenthal \& Ahern, Institutions, supra note 2, at 14-15. 
In terms of international documents, the MI Principles are the most detailed when it comes to the right to refuse treatment. Unfortunately, only the CRPD is hard law and therefore has more enforcement mechanisms than the MI Principles, thus the MI Principles are almost seen as obsolete now. ${ }^{183}$

\section{Mental Health Law in the United States}

\section{A. Background on United States Mental Health Law}

\section{Cultural Considerations}

Compared to many other countries, the United States is considered "advanced" in terms of acceptance of people with mental disabilities. Some would even argue that the United States is at the forefront of disability rights laws and advocacy. For example, some countries in Latin America have been influenced by the Americans with Disabilities Act (ADA) ${ }^{184}$ while creating their own mental health legislation ${ }^{185}$ and the CRPD was partially modeled on the ADA. ${ }^{186}$ However, this has not always been the case.

Historically, people with mental disabilities in the United States were regularly sent to prisons and shelters without any treatment. They were simply sent away and segregated from society. ${ }^{187}$ In the mid-nineteenth century, public asylums opened in pockets of the country to house people with mental disabilities. Unfortunately, individuals were often subjected to restraint, sedation, and experimental treatments while in these asylums. ${ }^{188}$

\section{The Rise of Antipsychotic Medications and Deinstitutionalization}

In the 1950s, advancement in psychotropic medications revolutionized how the government treated people with mental disabilities in institutional settings in the United States. ${ }^{189}$ After it was discovered that some newly created antipsychotic medications, particularly Chlorpromazine, could reduce or eliminate hallucinations and delusions in many individuals with schizophrenia, patients were no longer presumed destined to live in institutions and were subsequently deinstitutionalized. ${ }^{190}$ While this form of treatment made it easier to treat people with mental disabilities in the community, it also caused many other problems including increases in the misdiagnosis of mental illness and the misadministration of psychotropic medications. ${ }^{191}$

A second generation of antipsychotic medications was introduced in the 1990s and psychiatrists began prescribing them extensively. ${ }^{192}$ Among these new medications was Clozapine, seen as a novel breakthrough in antipsychotic medications due to its ability to alleviate psychotic symptoms without inducing the common

${ }^{183}$ However, the MI Principles retain significance today in those nations that have neither signed nor ratified the CRPD. See Perlin, Silenced, supra note 140, at 9-10 n. 13.

${ }^{184}$ The Americans with Disabilities Act of 1990, 42 U.S.C. $\S \S 12101-12213$ (codified as amended in scattered sections of 42 U.S.C. and 47 U.S.C.).

${ }^{185}$ Courtis, supra note 123 , at 115 .

${ }^{186}$ US International Council on Disabilities, Disability Advocates Call for Senate Action on Treaty Following Supreme Court Ruling in Bond Case (June 2014), http://www.usicd.org/detail/news.cfm?news_id=1744\&id=178 (last visited April 16, 2016) (discussing how the CRPD is modeled after the Americans with Disabilities Act).

${ }^{187}$ Stuart Anfang \& Paul S. Appelbaum, Civil Commitment - The American Experience 43 IsR J Psychiatry ReLATEd SCI 209-218 (2006).

${ }^{188}$ See Roy Porter, Madness: A Brief History (Oxford University Press, 2002); see also generally Gerald N. Grob, THE Mad Among Us: A History of the Care of America’s Mentally Ill (Free Press, 1994).

189 See 2 Perlin, supra note 9 , at $\S 3$ B-2.

${ }^{190}$ See Donald C. Goff, A 23-Year Old Man with Schizophrenia, 287 J. Am. Med. Ass'N. 3253-54, 3256 (2002); MichaEL L. Perlin, Law and Mental Disability $\S 2.08,214$ (1994). Many psychiatrists attribute the decline in state hospital beds solely to antipsychotic medication. See Johnson, supra note 23, at 38-39; see Mossman, supra note 22, at 1063; see also, Hyman ET AL., supra note 24 , at 5-7.

${ }^{191}$ Perlin, Mental Disability Law, supra note 9, at § 3B-2.

${ }^{192}$ Mossman, supra note 22, at 1069. 
extrapyramidal symptoms ${ }^{193}$ that typically accompanied therapy with conventional D2194 blockers. ${ }^{195}$ Clozapine also worked better than conventional neuroleptics ${ }^{196}$ and was thought to be better at reducing negative symptoms than conventional antipsychotic drugs. ${ }^{197}$ In short, Clozapine was seen to be a cure-all because it seemed to achieve superior therapeutic results with a much lower likelihood of extrapyramidal symptoms or the damaging neuromotor syndromes associated with neuroleptic drugs. ${ }^{198}$ Eventually it was discovered that patients who took Clozapine for extended periods of time had a small risk of developing agranulocytosis, ${ }^{199}$ a potentially fatal side effect in which the bone marrow stops producing white blood cells resulting in the patient's inability to fight bacterial infections. ${ }^{200}$ However, many of these side effects can be managed or avoided and thus Clozapine has continued to remain popular. ${ }^{201}$

\section{Present Day Considerations for Americans with Mental Disabilities}

In the United States, a person who enters a hospital voluntarily and shows no imminent risk of danger to himself or others may express the right to refuse treatment by stating he wishes to leave the hospital. A person admitted involuntarily, due to danger to self or others, does not have this option to leave, at least not initially. However, a person who is involuntarily committed does have the right to refuse treatment, with some exceptions. Although hospital staff may have authority to keep the patient in the institution, they may not treat him against his will, without a court order. This concept of the right to refuse treatment was built upon the basic constitutional rights to privacy, equal protection under the law, and due process. ${ }^{202}$

193 Extrapyramidal symptoms are common side effects of antipsychotic medications. These symptoms include acute dyskinesias and dystonic reactions, tardive dyskinesia, Parkinsonism, akinesia, akathisia, and neuroleptic malignant syndrome. Tamra Jean Courey, Detection, Prevention, and Management of Extrapyramidal Symptoms, 3 J. NuRSE PRACTITIONERS 464 (2007), accessible at http://www.medscape.com/viewarticle/561665.

${ }^{194}$ Dopamine is a naturally produced chemical in the body that binds to regions in the brain to help regulate emotions and movement. D2s, (or dopamine antagonists) are drugs that prevent these actions by blocking dopamine-binding sites without activating them. These medications are used to treat a variety of disorders including schizophrenia. Heidi Moawad, What is a Dopamine Antagonist? LiveSTRONG.COM, (Feb. 28, 2014), http://www.livestrong.com/article/232329-what-is-a-dopamine-antagonist/.

195 Michael J. Owens \& S. Craig Risch, Atypical Antipsychotics, in The American Psychiatric Press textbook of Pharmacology; see also, Meltzer \& Fatemi, supra note 25, at 760-761.

196 Thirty to 60 percent of schizophrenic patients who did not respond to the older drugs improved when they took Clozapine. See John Kane et al., Clozapine for the Treatment Resistant Schizophrenic: A Double-Blind Comparison with Chlorpromazine, 45 Archives Gen. Psychiatry 789, 789-796 (1988).

${ }^{197}$ David Pickar et al., Clinical and Biologic Response to Clozapine in Patients with Schizophrenia: Crossover Comparison with Fluphenazine, 49 Archives Gen. Psychiatry 345, 348 (1992).

198 Daniel E. Casey, Effects of Clozapine Therapy in Schizophrenic Individuals at Risk for Tardive Dyskinesia, 59 J. Clinical Psychiatry 31, 31-37 (Supp. 3, 1998); Marvin I. Herz et al., Practice Guideline for the Treatment of Patients with Schizophrenia, 154 Am. J. Psychiatry 2, 17, 19 (Supp. Apr. 1997).

199 "Clozapine was first tested in the 1960s but was withdrawn from general use" because of this problem. HYMAN ET AL., supra note 25, at 29. Initial estimates placed the risk of agranulocytosis at 1 percent. Id; A more recent estimate sets the risk at only thirty-eight hundredths of a percent. Gilbert Honigfeld, Effects of the Clozapine National Registry System on Incidence of Deaths Related to Agranulocytosis, 47 Psychiatric Services 52, 56 (1996).

200 Dorland's, supra note 23, at 1489, 40, 984; Philip A. Pizzo, The Compromized Host, in 2 CECIL TEXTBOOK OF Medicine 1571 (Lee Goldman \& J. Claude Bennet eds., 21st ed. 2000). Research indicates other side effects of these drugs including weight gain, sedation, excess salivation, and orthostatic hypotension (head rushes or dizzy spells), as well as temporary increases in body temperature. Ana Campbell \& Laura Obiso, 13-106 Attorneys' Textbook of Medicine (3d ed.) $\S 106.03$.

201 Jimmi Nielsen et al., Termination of Clozapine Treatment Due to Medical Reasons: When is it Warranted and How Can it be Avoided?, 74 J. Clinical Psychiatry 6, 603-13 (2013).

202 See e.g., Bee v. Greaves, 744 F.2d 1387, 1393 (10th Cir. 1984), cert. denied, 469 U.S. 1214 (1985) ([there exists a] constitutional "liberty interest in freedom from physical and mental restraint of the kind potentially imposed by antipsychotic drugs"); Rogers v. Okin, 634 F.2d 650, 653 (1st Cir. 1980), (there is a constitutional right "in being left free by the State to decide ... whether to submit to the serious and potentially harmful medical treatment that is represented by the administration of antipsychotic drugs" derived from "the penumbral right to privacy, bodily integrity or personal security"); Rennie $v$. Klein, 462 F. Supp. 1131, 1144 (D.N.J. 1978), modified on other grounds, 476 F. Supp. 1294 (D.N.J. 1979), vacated and remanded on 
Culturally speaking, in the United States, an individual's rights are traditionally paramount to competing government interests, including the rights of privacy and liberty among people with mental disabilities. In the case of involuntary commitment of an individual, the United States Supreme Court has articulated only two conditions under which the government's competing interest in insuring public health and safety may supersede those of individuals: (1) in emergency situations; and (2) in situations where the individual is unable to care for or control himself. ${ }^{203}$

Through their police powers, government officials may exercise broad discretion to protect public health, safety, welfare, and moral behavior. The state may even employ its police power authority to involuntarily restrain patients with mental disabilities in hospital settings in certain situations. The state's police power authority stems from its legitimate interest in preventing persons with mental disabilities from harming themselves or others. "This principle of 'societal selfdefense' has been applied ubiquitously to restrain any person who endangers the safety of others."204

The first government interest exception to a patient's constitutional right to refuse treatment is when a patient is an "imminent danger to self or others." In these situations, a doctor may provide involuntary treatment, however emergency treatment must be discontinued once the immediate danger has passed, unless the patient agrees to continued treatment and provides informed consent. ${ }^{205}$ The second exception allows treatment when the individual is deemed incompetent, and thus unable to make decisions. ${ }^{206}$ It is important to note here that "mental disabilities" and "incompetence" are not mutually exclusive categories. Because someone has a mental disability does not automatically render him incompetent. In fact, in 1978, the Federal District Court of New Jersey held that mental illness "is not the equivalent of incompetence, which renders one incapable of giving informed consent to medical treatment."207

\section{Access to Adequate Counsel}

The right to refuse treatment is not self-executing in the United States. It requires a court order or some other type of implementing action to be effective. Thus the right to adequate counsel is especially important in these

other grounds, 458 U.S. 1119 (1982), aff'd on reh'g, 720 F.2d 266 (3rd Cir. 1983) ("the right of privacy is broad enough to include the right to protect one's mental processes from governmental interference" and the "individual's autonomy over his own body"); Anderson v. State, 135 Ariz. 578, 582, 633 P.2d 570, 574 (Ariz. Ct. App. 1982) ([there exists a] due process liberty interest in freedom from bodily restraint " $[\mathrm{t}] \mathrm{o}$ the extent that medication is administered forcibly and/or for the purpose of accomplishing bodily restraint"); Rogers v. Commissioner of Dep't of Mental Health, 390 Mass. 489, 458 N.E.2d 308, 314 (1983) (right to refuse psychotropic medication "has constitutional and common law origins ... which protect each person's 'strong interest in being free from nonconsensual invasion of his bodily integrity"'); In re K.K.B., 609 P.2d 747, 749-750 (Okla. 1980) (psychotropic drugs "are intrusive in nature and an invasion of the body" in violation of constitutional right to privacy).

203 See Addington v. Texas, 441 U.S. 418, 426 (1979) (holding that "the state has a legitimate interest under its parens patriae powers in providing care to its citizens who are unable because of emotional disorders to care for themselves. The state also has authority under its police power to protect the community from the dangerous tendencies of some who are mentally ill").

${ }^{204}$ See Jennifer Gutterman, Note, Waging a War On Drugs: Administering a Lethal Dose to Kendra's Law, 68 FordHAM L. REv. 2401, 2427 (2000).

${ }^{205}$ Lloyd I. Sederer, M.D., The Right to Treatment and the Right to Refuse Treatment, (Aug. 6, 2013), http://careforyour mind.org/the-right-to-treatment-and-the-right-to-refuse-treatment/ (last visited April 16, 2016); see also United States v. Charters, 863 F.2d 302, 305 (4th Cir. 1988) (en banc) (holding that antipsychotic drugs intrude sufficiently upon "bodily security" to implicate a "protectible liberty interest"); Project Release v. Prevost, 722 F.2d 960, 971-979 (2d Cir. 1983) (finding that there is a liberty interest in refusing medication), aff'g 551 F. Supp. 1298, 1309 (E.D.N.Y. 1982) ("Forcible medication can alter mental processes and limit physical movement, and therefore is analogous to bodily restraint.")

${ }^{206}$ See Addington, supra note 203 and accompanying text.

${ }^{207}$ Rennie v. Klein, 462 F. Supp. 1131, 1145 (D.N.J. 1978), modified on other grounds, 476 F. Supp. 1294 (D.N.J. 1979), vacated and remanded on other grounds, 458 U.S. 1119 (1982), aff'd on reh'g, 720 F.2d 266 (3rd Cir. 1983); see also Charles M. Culver et al., ECT and Special Problems of Informed Consent, 137 Ам. J. Psychiatry 586 (1980) ("in the view of most psychiatrists, serious mental illness does not usually render a patient incapable of making informed decisions about treatment"); Robert Weinstock et al., Competence to Give Informed Consent for Medical Procedures, 12 Bull. Am. Acad. Psychiatry \& L. 117, 124 (1984) (study indicating that psychiatric patients who are incompetent for some purposes may nonetheless be competent to give informed consent). But see Harvey Schwed, Social Policy and the Rights of the Mentally Ill: Time for Re-examination, 5 J. Health Pol., Pol'y \& L. 193, 195 (1980) (implying that individuals suffering from severe mental illness retain very little, if any, rational reasoning power to make treatment decisions). 
cases. $^{208}$ Unfortunately, data suggests that, in many jurisdictions, legal counsel is inadequate, disinterested, uninformed, and in some cases even hostile toward clients with mental disabilities. ${ }^{209}$ Unfortunately, only one case involving the right to refuse treatment has recognized the need for adequate counsel. In Rennie v. Klein, ${ }^{210}$ one of the first federal cases to find a substantive constitutional right to refuse treatment, the court originally mandated the appointment of counsel ${ }^{211}$ but later retreated from this position, instead requiring only the presence of "patient advocates" 212 to serve as "informal counsel to patients who wish to refuse [antipsychotic medication]." 213 The court further provided that "Patient advocates may be attorneys, psychologists, social workers, registered nurses, or paralegals, 'or have equivalent experience."”214

\section{B. The United States}

\section{Mental Health Law and the United States Constitution}

The right to refuse treatment is not automatic in the United States and constitutional rights are not absolute. Instead they must be balanced against the government's interest for infringement. ${ }^{215}$

In 1978, in the landmark case, Rennie v. Klein, ${ }^{216}$ the United States District Court for the State of New Jersey became the first court in the United States to officially recognize that involuntarily committed patients have a constitutional right to refuse treatment in the United States. ${ }^{217}$ The Supreme Court has also upheld the constitutionally protected right to refuse treatment. ${ }^{218}$ However, the precise source of that right is in contention, as the Constitution does not expressly speak to the right to refuse treatment. ${ }^{219}$

Important constitutional rights at play with respect to the right to refuse treatment are the First Amendment's right of free speech, the Sixth Amendment's right to a fair trial, the Eighth Amendment's right to freedom from cruel

208 See e.g., Bruce Winick, Restructuring Competency to Stand Trial, 32 U.C.L.A. L. Rev. 921, 941 (1985); Michael L. Perlin, Fatal Assumption: A Critical Evaluation of the Role of Counsel in Mental Disability Cases, 16 LAW \& Hum. Behav. 37, 47 (1992) [hereinafter Perlin, Fatal Assumption]; see also Alan H. Macurdy, The Americans With Disabilities Act: Time For Celebration, or Time for Caution?, 1 PuB. InT'L L.J. 21, 29 (1991); John Parry, Rights Aplenty But Not Enough Money: A Paradox in Federal Disability Policies, 12 Mental \& Physical Disability L. ReP. 486 (1988) (articulating that while there has been legislation to enhance the civil rights of persons with disabilities, the laws are not always fully implemented due to the lack of funding and other resources).

209 Perlin, Fatal Assumption, supra note 208, at 43.

${ }^{210}$ Rennie, supra note 207, suppl., 476 F. Supp. 1294 (D.N.J. 1979), mod., 653 F. 2d 836 (3d Cir. 1981), vacated and remanded, 458 U.S. 119 (1982), on remand, 720 F. 2d 266 (3d Cir. 1983); see generally Perlin, Mental Disability Law, supra note 9 , at $\S \S 5.10-5.21$.

211 Rennie, supra note 207, at 1147.

${ }^{212} I d$. at $1311,1313$.

213 Id. at 1311.

214 Id. at 1313.

215 See Youngberg v. Romeo, 457 U.S. 307, 321 (1982); Rogers v. Okin, 478 F. Supp. 1342 (D. Mass. 1979), modified, 634 F.2d 650 (1st Circ. 1980), vacated and remanded sub non, Mills v. Rogers, 457 U.S. 291, 299 (1982), on state court certification sub nom, Rogers v. Comm'r Dep't of Mental Health, 58 E.2d 9Mass. 1983), on remand, 738 F.2d 1 (1st Circ. 1984).

216 Rennie, supra note 207.

217 The district court issued two opinions in Rennie. The first opinion was based on a motion for a preliminary injunction filed on behalf of John Rennie. Id. The second opinion was generated by a class action filed on behalf of patients of five New Jersey state mental hospitals based on John Rennie's amended complaint. 476 F. Supp. 1294 (D.N.J. 1979), aff'd in part, modified in part, and remanded, 653 F.2d 836 (3d Cir. 1981) (en banc), vacated and remanded, 458 U.S. 1119 , 102 S. Ct. 3506 (1982), on remand, 720 F.2d 266 (3d Cir. 1983).

${ }^{218}$ See e.g., Cruzan v. Director, Missouri Dep't of Health, 497 U.S. 261 (1990) (upholding a competent patient's right to refuse medical treatment and upholding the Missouri Supreme Court's requirement of clear and convincing evidence of the treatment preference of an incompetent patient under the substituted judgment standard for medical treatment); see also e.g., Riggins, supra note 27 and accompanying text; see also e.g., Sell v. United States, 539 U.S. 166 (2003) (placing extreme limits on the authority of a lower court to administer antipsychotic medication to a criminal defendant solely for the purpose of making him competent to stand trial); see also e.g. Harper, supra note 107 and accompanying text).

219 Winick, supra note 13, at 10,13. 
and unusual punishment, and the Fourteenth Amendment's guarantee of due process. ${ }^{220}$ Some courts have also supported the right to refuse treatment via the Fourth Amendment's right of privacy and/or the substantive due process right to bodily integrity, however, discussion of the Fourth Amendment is beyond the scope of this article. ${ }^{221}$

\section{Adjudication of United States Mental Health Law}

There has been a plethora of case law in the United States regarding mental health law, much of which is beyond the scope of this article. What follows is a brief summary of a few of the keystone cases that shaped the current right to refuse treatment for people with mental disabilities in institutions in the United States. It should be noted at the outset that there is extensive debate among legal scholars and professionals as to what that prevailing right actually is.

a. First Amendment. Historically, the most common constitutional provision cited to support the right to refuse treatment is the Freedom of Speech Clause contained in the First Amendment ${ }^{222}$ with the argument being that the First Amendment encompasses the right to think and say what one wants. Thus, persons with mental disabilities should be free from government action (forced treatment) that interferes with one's thought process absent an overriding risk to a governmental interest. ${ }^{223}$

b. Eighth Amendment. The Eighth Amendment's protection against cruel and unusual punishment has been relied on in a variety of cases to support the right to refuse treatment. Courts have found that simply because an act is characterized as "treatment" does not necessarily make it immune from Eighth Amendment scrutiny. ${ }^{224}$ In Mackey v. Procunier (1973), ${ }^{225}$ a state prisoner was administered a drug against his will as part of an aversive conditioning behavior program. The drug caused paralysis, difficulty breathing, and fright. ${ }^{226}$ The Supreme Court held that the experimental use of the drug (succinylcholine) on conscious prisoners was inappropriate due to the intentional nature of the "aversive treatment" and the cruel and unusual side effects of the drug. In fact, the Court noted, "it is not recommended for administration to fully conscious patients, apparently because of its frightening effects." 227

In Rennie v. Klein (1978), 228 the New Jersey District Court held that the Eighth Amendment indeed prohibited psychiatric treatment in mental institutions when the treatment was "found to have no proven therapeutic value," "its use was not recognized as acceptable medical practice," "the adverse effects seemed unnecessarily harsh," or it was "used improperly and for punishment rather than as part of an ongoing psychotherapeutic program."229

${ }^{220}$ See Perlin et al., Therapeutic Jurisprudence, supra note 69, at 112; Dora W. Klein, Unreasonable: Involuntary Medications, Incompetent Criminal Defendants, and the Fourth Amendment, 46 SAN Diego L. Rev. 161, 162 (2009).

${ }^{221}$ Winick, supra note 13, at 25-41; see also, e.g., Cruzan, supra note 219 and accompanying text).

${ }^{222}$ See generally, Winick, supra note 13.

${ }^{223}$ Id. at 25-41; see also Kaimowitz v. Michigan Department of Mental Health, Civ. No. 73-19434-AW (Wayne County [Mich.] Cir. Ct., July 10, 1973) (enjoining experimental psychosurgery on a detainee and holding that the First Amendment "protects the generation and free flow of ideas from unwarranted interference with one's mental processes.") Id. at 822; see also e.g., Mackey, supra note 7 (holding that that the forced administration of the drug succinylcholine, which caused the patient frightening nightmares, raised serious constitutional questions regarding "impermissible tinkering with the mental processes.") Id. at 878 .

${ }^{224}$ See Trop v. Dulles, 356 U.S. 86, 95, 78 S. Ct. 590, 595 (1958) (finding that the legislative classification of a statute is not conclusive in determining an Eighth Amendment violation. The statute's substance must be examined as "even a clear legislative classification of a statute as 'nonpenal' would not alter the fundamental nature of a plainly penal statute"); Knecht v. Gillman, 488 F.2d 1136, 1139 (8th Cir. 1973).

${ }^{225}$ Mackey, supra note 7.

${ }^{226} \mathrm{Id}$. at 878 .

${ }^{227} \mathrm{Id}$.

${ }^{228}$ Rennie, supra note 207.

${ }^{229}$ Id. at 1143. 
c. Fourteenth Amendment. Many cases focus on the Fourteenth Amendment's Due Process Clause.

In 1972, the Supreme Court held that criminal defendants with mental disabilities who are also incompetent to stand trial cannot be indefinitely committed on the basis of incompetence to stand trial alone ${ }^{230}$ and that the nature and duration of the civil commitment must bear a reasonable relationship to the purpose of the commitment. ${ }^{231}$ In 1975, the Supreme Court again recognized that states cannot confine a mentally disabled person who is a danger to himself or others "without more," holding that "'mental illness' alone cannot justify a state's locking up a person against his will and keeping him indefinitely in simple custodial confinement."232

Going one step further, the Supreme Court in Youngberg v. Romeo (1982) held that, in addition to the fundamental human rights of "adequate food, shelter, clothing and medical care," 233 patients also have constitutionally protected Fourteenth Amendment liberty interests in "conditions of reasonable care and safety,"234 "freedom from bodily restraint," 235 and "such minimally adequate or reasonable training to ensure safety and freedom from undue restraint." $236 \mathrm{Mr}$. Romeo was involuntarily admitted to a Pennsylvania state institution where he was restrained for many hours a day and suffered numerous injuries. ${ }^{237}$ His mother brought suit against the institution officials for violations of his Fourteenth Amendment liberties claiming that they knew or should have known about the ill treatment of her son and that they failed to take appropriate remedial and preventative actions. ${ }^{238}$

In determining whether an individual patient's Fourteenth Amendment rights have been violated, the liberty interests identified by the Youngberg court must be balanced against relevant state interests. ${ }^{239}$ The holding in Youngberg shows the importance of individual rights, including freedom from restraint and conditions of adequate care, which all relate back to the right to refuse and the concept of patient autonomy and civil liberties. ${ }^{240}$

In 1990, the Supreme Court explicitly defined the "right to refuse treatment's" place within the Fourteenth Amendment's Due Process Clause in Washington v. Harper. ${ }^{241}$ Walter Harper, an inmate in the Washington state prison system, had a history of violence when not on antipsychotic medications. ${ }^{242}$ During his incarceration, he was appropriately transferred to the Special Offender Center (SOC), - a state institution for convicted offenders with serious psychiatric problems - was diagnosed with manic-depressive disorder and was forced to take psychiatric medication against his will. ${ }^{243}$ Harper filed suit alleging that the SOC failed to hold a judicial hearing before forcefully medicating him, thus violating his Fourteenth Amendment right to due process. ${ }^{244}$ In supporting the state's right to administer medication, the Supreme Court found that the forceful administration of psychiatric medication against Harper's will did not violate the Due Process clause of the Fourteenth Amendment. Rather, the Court held that the Due Process Clause permits the state to treat a prisoner with a "serious mental illness" with antipsychotic drugs without his consent, if the inmate is "dangerous to himself or others and the treatment is in the inmate's medical interest." ${ }^{45}$ It is worth noting that the Harper court only addressed the right to refuse in the context of "prisoners" and left open the question of whether this right should apply to civil institutional settings as well. ${ }^{246}$

${ }^{230}$ See Jackson v. Indiana, 406 U.S. 715, 731 (1972).

231 Riggins, supra note 27, at 138.

232 See O'Connor, supra note 218, at 575.

233 Youngberg, supra note 215, at 315.

${ }^{234} I d$. at 324.

${ }^{235} \mathrm{Id}$. at 319.

${ }^{236} \mathrm{Id}$. at 321 .

237 Youngberg, supra note 215, at 308.

${ }^{238} \mathrm{Id}$.

${ }^{239} I d$. at 321 . In this scenario, "state interest" is interpreted to provide for the "safety for all residents and personnel within the institution." Id. at 324.

${ }^{240}$ See SAKS, supra note 54, at 5-19 (discussing the debate between treatment of patients with mental illness and patient autonomy and human rights).

241 Harper, supra note 107.

242 Id. at $213-214$.

${ }^{243} I d$. at 214 .

244 Id. at 228.

245 Harper, supra note 107, at 217.

246 Dennis Cichon, The Right to “Just Say No": A History and Analysis of the Right to Refuse Antipsychotic Drugs, 53 LA. L. REv. 283, 288 (1992). 
Harper is a significant decision because it shows the tendency of the Court to give deference to medical professionals in determining treatment for psychiatric patients, rather than making these decisions through the judicial process. ${ }^{247}$ This can however be detrimental to the patient in that it leaves the treatment plan in the hands of the medical professional and leaves little room for oversight to ensure a patient's rights aren't being infringed upon.

Alternatively, in Riggins v Nevada (1992), ${ }^{248}$ the Supreme Court held that the Fourteenth Amendment's Due Process Clause did protect Mr. Riggins' interest in avoiding the administration of involuntary drugs. David Riggins was convicted of murder and while awaiting trial complained of hearing voices and trouble sleeping. He was treated with antipsychotic medication. ${ }^{249}$ The Court found Mr. Riggins competence to stand trial and his defense team requested that he be taken off the medication accordingly for the duration of the trial. The defense argued that "(1) [the] continued administration of these drugs infringed on his freedom; (2) the effect on his demeanor and mental state during trial would deny him due process; and (3) because he intended to offer an insanity defense at trial, he had a right to show jurors his true mental state." 250 The Court agreed holding that the forced administration of antipsychotic drugs during trial violated Mr. Riggins' rights protected by both the Sixth and Fourteenth Amendments. ${ }^{251}$ The Court further noted, "The forcible injection of medication into a nonconsenting person's body represents a substantial interference with that person's liberty." 252

More recently, in Sell v. United States (2003), ${ }^{253}$ the Supreme Court imposed strict limitations on the rights of lower courts to forcibly administer antipsychotic medication to a criminal defendant who had been deemed incompetent to stand trial for the sole purpose of making him competent to stand trial. ${ }^{254}$

\section{Domestic Mental Health Legislation in the United States}

The United States Congress has produced only limited amounts of domestic legislation on the right to refuse treatment for people with mental disabilities as historically this right was guaranteed via the United States Constitution as outlined above.

However, in 1963, President John F. Kennedy signed into legislation the Community Mental Health Centers Act (CMHA). ${ }^{255}$ Through federal funding, this innovative law relocated people with mental disabilities from prisons and shelters, as well as facilitated the deinstitutionalization of people with mental disabilities, into comprehensive government supported community mental health centers. ${ }^{256}$ The idea was to help integrate people with mental disabilities into society while still receiving mental health treatment at work or at home. ${ }^{257}$ President Kennedy's vision was to build 1,500 new facilities with the hope of reducing the approximately 500,000 people in state mental hospitals to half that number. ${ }^{258}$ While the idea was good in theory, unfortunately, the funding was not adequate to maintain the centers and the program floundered. The legislation failed to allocate sufficient funding for the centers in the long term. Instead, the funding was left to the states and localities. Unfortunately, that support never came to

247 Gary, Melton Psychological Evaluations for the Courts: A Handbook for Mental Health Professionals and LAWYERS 134, 350-351 (The Guilford Press, 2nd ed. 1997).

248 Riggins, supra note 27.

249 Id. at 112.

${ }^{250} \mathrm{Id}$.

${ }^{251} I d$.

252 Riggins, supra note 27, at 135 (citing Washington v. Harper, 494 U.S. 210, 229 (1990)).

253 Sell, supra note 218.

254 Id. at $180-183$.

25542 U.S.C., Ch. 33 (1963).

256 “The Community Mental Health Care Act of 1963: Still Pursuing the Promise of Reform 50 Years Later," Young Minds Advocacy Project, available at http://www.youngmindsadvocacy.org/the-community-mental-health-act-of-1963/ (last visited April 16, 2016) [hereinafter Pursuing the Promise].

${ }^{257}$ Michelle R. Smith, “50 Years Later, Kennedy’s Vision for Mental Health Not Realized,” The Associated Press (Oct. 20, 2013), available at http://www.seattletimes.com/nation-world/50-years-later-kennedyrsquos-vision-for-mental-health-not-realized/ (last visited April 16, 2016).

258 Id. 
fruition. ${ }^{259}$ During President Ronald Reagan's administration, leftover funding from the act was converted to a mental health grant thus allowing states to spend the funds at their discretion.

While some states tried to provide quality community mental health care, others did not even attempt it. Those that did were not able to sustain their initiatives in the long run. With budget cuts, mental health programs tended to bear the brunt of the defunding. ${ }^{260}$ As a result, many public health systems were, and in many cases still are, understaffed and underfunded. ${ }^{261}$

\section{United States Mental Health Law in Action}

In the United States, people with mental disabilities are largely overrepresented in prisons and in the homeless population. Studies show that individuals with mental disabilities tend to be arrested more than individuals with no such diagnosis, and individuals with past civil commitments have a higher likelihood of arrest than individuals who voluntarily sought psychiatric help. ${ }^{262}$ Arguably this is due to the deinstitutionalization triggered by President Kennedy's CMHA initiatives the middle of the twentieth century. With the total number of beds available to people with mental disabilities cut by up to 90 percent during the CMHA era, people with mental disabilities no longer had places to sleep and ended up homeless, abusing substances, or in prison. ${ }^{263}$ Although many mental health advocates argue for people with mental disabilities to live on their own or with the assistance of community-based centers rather than in institutions, deinstitutionalization must be a gradual and community-based process to ensure that people do not end up homeless or in prisons.

\section{Mental Health Law in Latin America}

\section{A. Background on Latin American Mental Health Law}

\section{Cultural Considerations}

Historically, Latin American disability policy has excluded persons with mental disabilities from social aspects of life, with limited social participation. ${ }^{264}$ There are many legally and socially imposed barriers to participation in society for people with disabilities in most Latin American countries. ${ }^{265}$ Many nations in the region still lack physical and social access to public buildings, transportation, education, and employment. Further, Latin American societies have traditionally viewed people with mental disabilities as people needing charity and special protection. ${ }^{266}$

From the 1960s to the 1980s, the Pan American Health Organization (PAHO), a member of the UN system that serves as the Americas regional office of the World Health Organization (WHO) and helps improve health and quality of life in the Americas, ${ }^{267}$ promoted many international conferences for the improvement of mental health care in Latin America and the Caribbean. Many countries developed community mental health services and programs during that time, including Brazil. ${ }^{268}$

${ }^{259} I d$.

${ }^{260} I d$.

261 Pursuing the Promise, supra note 256.

262 Anfang \& Appelbaum, supra note 187; “Mental Illness and Homelessness," National Coalition for the Homeless (July 2009), http://www.national homeless.org/factsheets/Mental_Illness.html (last visited April 16, 2016); H. Richard Lamb \& Linda E. Weinberger, Review: Persons with Severe Mental Illness in Jails and Prisons, 49 Psychiatr Serv. 483-492 (1998).

263 Smith, supra note 257.

264 Courtis, supra note 123 , at 110.

265 Id.

${ }^{266} \mathrm{Id}$.

267 “About PAHO,” Pan American Health Organization (last updated Jan. 28, 2013), http://www.paho.org/hq/index.php? option=com_content\&view=article\&id=91\&Itemid=220\&lang=en (last visited April 16, 2016).

${ }^{268}$ Pan American Health Organization [PAHO], Innovative Mental Health Programs in Latin America and the Caribbean, (Jose Miguel Caldas de Almeida \& Alex Cohen eds., 2008), available at http://www.gulbenkianmhplatform.com/ conteudos/00/ 83/00/01/Innovative-programms_6775.pdf (last visited April 16, 2016) [hereinafter Innovative Mental Health]. 


\section{The Caracas Declaration, 1990}

In 1990, many Latin American countries signed the Caracas Declaration, ${ }^{269}$ designed to promote respect for human and civil rights of persons with mental disabilities. ${ }^{270}$ The Declaration played an important role in revising and redrafting domestic mental health legislations to guarantee civil rights for people with mental disabilities in Latin America. The goal was to create a framework for restructuring conventional psychiatric care in Latin America to bring it into compliance with the human rights principles of the WHO and the PAHO. ${ }^{271}$ It also called for the integration of mental health considerations into primary care services and a shift from hospitalbased care to community-based care with accessible, decentralized care, and prevention for persons with disabilities. ${ }^{272}$

Soon after the Caracas Declaration, The Initiative for the Restructuring of Psychiatric Services 273 ("The Initiative") was launched by the PAHO and the WHO in collaboration with several countries, international organizations, and mental health experts. The Initiative actively promotes and supports mental health reform efforts in Latin America and the Caribbean, thus further contributing to the development of domestic mental health policies in several nations in the region. ${ }^{274}$

\section{Present Day Considerations for Latin Americans with Mental Disabilities}

Successful and innovative reform processes have taken place in most Latin American and Caribbean countries as a result of the Caracas Declaration and the legislative and policy changes discussed above. Many Latin American countries have developed community-based services and have downsized and/or improved psychiatric hospital services. ${ }^{275}$ Mental health considerations have also been integrated into primary care in many countries. ${ }^{276}$ Furthermore, there has been a strong movement on health promotion and prevention, which has been a major component of mental health reform processes in many countries of the region, including Brazil, Cuba, Chile, El Salvador, Nicaragua, Guatemala, and Panama, among others. ${ }^{277}$

As a result of the Caracas Declaration, as of 2004, more than three quarters of the participating countries in Latin America and the English Speaking Caribbean have a national mental health plan or have enacted mental health legislation. ${ }^{278}$ Sadly, the presence of mental health laws does not always equate to implementation or regular enforcement. ${ }^{279}$ This is true for many nations in Latin America and the Caribbean, and unfortunately many of these nations are still not in compliance with international mental health standards. ${ }^{280}$

269 PAHO/ WHO (1990), The Caracas Declaration, Caracas.

270 Renato D Alarcon, Mental Health and Mental Health Care in Latin America, World PsychiAtry (Feb. 2003$) ; 2$ (1): 54-56, available at http://www.ncbi.nlm.nih.gov/pmc/articles/PMC1525063/ (last visited April 16, 2016).

${ }^{271}$ Monica Bonis (Regional Advisor in Health Legislation), The Impact on the Modernization of Mental Health Legislation in Latin America and the English-Speaking Caribbean [PAHO/WHO] available at http://www.coedu.usf.edu/zalaquett/gua/ CaracasDeclarationMentalHealthAmsterdam.pdf (last visited April 16, 2016).

272 José Miguel Caldas de Almeida, Marcela Horvitz-Lennon, Mental Health Care Reforms in Latin America: An Overview of Mental Health Care Reforms in Latin America and the Caribbean Psychiatric Services 2010, 61 J. PSYCH SERV. 218,218 (2010), available at http://ps.psychiatryonline.org/article.aspx?articleid=101212\#KD6131039 (last visited April 16, 2016).

273 PAHO/ WHO (1990), Initiative for the Restructuring of Psychiatric Care in Latin America, Caracas.

274 See Levav, I., Restrepo, H., \& Guerra de Macedo, C., The Restructuring of Psychiatric Care in Latin America: a New Policy for Mental Health Services, 15 J. Public Health Pol'y 71 (1994).

${ }^{275}$ See World Health Organization, World Family Doctors Caring for People [WONCA], Integrating Mental Health in Primary Care: A Global Perspective, 89 (2008), available at http://www.who.int/mental_health/resources/ mentalhealth_PHC_2008.pdf (last visited April 16, 2016) [hereinafter WHO/WONCA Report].

276 Innovative Mental Health, supra note 268 , at V.

277 Id. at VI.

278 WHO, Mental Health Atlas 13-16 (2005).

279 See e.g., Perlin, What's Good is Bad, supra note 83, at 246 ("Mental disability law is strewn with examples of 'paper victories....") (quoting Michael Lottman, Paper Victories and Hard Realities, in PaPer Victories And Hard REALITIES: THE Implementation of the Legal and Constitutional Rights of the Mentally Disabled 93 (Valerie J. Bradley \& Gary J. Clarke eds., 1976)).

280 See generally Courtis, supra note 123. 
There are, however, a number of important regional human rights documents that give rise to the right to refuse treatment in Latin America. These include the American Convention on the Rights and Duties of Man, (1948), ${ }^{281}$ the American Convention on Human Rights, (1969), ${ }^{282}$ and the Inter-American Convention for the Elimination of all Forms of Discrimination against Persons with Disabilities, (1990). ${ }^{283}$ These documents all give positive rights to persons with mental disabilities regarding freedom and liberty.

For example, the American Convention on the Rights and Duties of Man includes a right to life, liberty, and security of person ${ }^{284}$ and a provision that speaks to the right to equality before the law. ${ }^{285}$ The American Convention on Human Rights states that persons have a right to have their physical, mental, and moral integrity respected under Article $5^{286}$ and Article 7 provides that persons have a right to personal liberty and freedom from arbitrary detention. ${ }^{287}$ The Inter-American Convention for the Elimination of all Forms of Discrimination against Persons with Disabilities' definition of a disability merges both a medical and social model and the definition of discrimination is influenced by the United States' Americans with Disabilities Act. ${ }^{288}$

Although some of the legislation is in line with international standards, many Latin American nations are still lagging behind mental disability rights laws that exist in the United States and in other developed nations across the world. ${ }^{289}$

\section{Access to Adequate Counsel}

Article 18 of the American Convention on the Rights and Duties of Man guarantees every person access to the court system to ensure respect for his legal rights, and requires the courts to protect him from acts that would prejudice him or violate any of his fundamental constitutional rights. ${ }^{290}$ Article 26 guarantees due process of law. ${ }^{291}$ Unfortunately, provisions that specifically address the right to counsel are missing from these conventions. ${ }^{292}$

\section{Adjudication of Latin American Mental Health Law}

Regional human rights commissions and courts are vital to ensuring that international human rights are protected and enforced and serve as an engine for political and social change. ${ }^{293}$ The Inter-American Commission on Human Rights (IACHR), ${ }^{294}$ an arm of the Organization of American States (OAS) established in 1959, works with the Inter-American Court of Human Rights (IACtHR), created in 1979, to help protect human rights within the

281 American Declaration of the Rights and Duties of Man, OEA/Ser.L./V.II.23, doc. 21, rev. 6 (1948), reprinted in Basic Documents Pertaining to Human Rights in the Inter-American System, OEA/Ser.L.V./II.82, doc. 6, rev. 1 [hereinafter The Rights and Duties of Man].

282 Organization of American States (OAS), American Convention on Human Rights, Nov. 22, 1969, O.A.S.T.S. No. 36, 1144 U.N.T.S. 123 [hereinafter American Convention on Human Rights].

283 Organization of American States (OAS), Inter-American Convention for the Elimination of all Forms of Discrimination against Persons with Disabilities, June 7, 1999, AG/RES. 1608 (XXIX-O/99) [hereinafter Inter-American Convention].

284 The Rights and Duties of Man, supra note 281, at Article I.

285 Id. at Article II.

286 American Convention on Human Rights, supra note 282, at Article 5.

${ }^{287}$ Id. at Article 7.

${ }^{288}$ Courtis, supra note 123 , at 115 .

289 Id. at 121.

290 The Rights and Duties of Man, supra note 281, at Article 18.

291 Id. at Article 26.

292 See generally id.

${ }^{293}$ Michael L. Perlin \& Yoshikazu Ikehara, Creation of a Mental Disability Rights Tribunal for Asia and the Pacific: Its Impact on China?, (NYLS Legal Studies Research Paper No. 10/11 \#19, 2011), available at http://papers.ssrn. com/sol3/papers. cfm?abstract_id=1744196 (last visited April 16, 2016).

294 The Inter-American Commission on Human Rights hears cases under the jurisdiction established by its authority under the OAS (Organization of American States) Charter, as well as cases under authority established by the American Convention on Human Rights. See Thomas Buergenthal \& Sean D. Murphy, Public International Law: In a Nutshell 145-147 (3d ed. 2002) (describing the hierarchy of the OAS establishing the Inter-American Commission on Human Rights and the American Convention establishing both the International Commission of Human Rights and an Inter-American Court of Human 
Americas. ${ }^{295}$ In 1999, the pivotal case of Victor Rosario Congo v. Ecuador was decided by the IACHR. ${ }^{296}$ In that case, Mr. Congo, a 48-year-old mentally disabled Ecuadorian man, was imprisoned at the Machala Social Rehabilitation Center ${ }^{297}$ where he was beaten with a club on the scalp by a guard, deprived of medical treatment, kept naked, and forced to endure complete isolation. ${ }^{298} \mathrm{He}$ eventually died of malnutrition, hydro-electrolitic imbalance, and heart and lung failure as a result of the State's acts. ${ }^{299}$

The IACHR found the State responsible for the negligence and willful conduct of its agents who violated Mr. Congo's right to humane treatment under Article 5 of the American Convention on Human Rights. ${ }^{300}$ They also found that Mr. Congo's solitary confinement constituted inhuman and degrading treatment in violation of Article 5(2) $)^{301}$ of the American Convention on Human Rights, especially in light of the fact that during his isolation he was unable to satisfy basic needs ${ }^{302}$ such as water, clothing, and medical attention. ${ }^{303}$ Additionally, the IACHR found that the State had failed to take measures within its power to ensure the right to life of a person who, "partly because of his state of health and in part owing to injuries inflicted on him by a State agent, was defenseless, isolated and under its control" thus violating Article $4(1)^{304}$ of the American Convention on Human Rights. ${ }^{305}$

This was a monumental decision as it shows the Commission's willingness to use regional human rights documents to hold States responsible for the actions of its agents.

Another pivotal case coming from the Inter-American system is Ximenes-Lopes v. Brazil (2006) ${ }^{306}$ decided by the IACtHR. ${ }^{307}$ Not only was this the first Brazilian case heard by the Court, but it also was the first decision regarding persons with disabilities heard by the Court. In 1998, Mr. Ximenes-Lopes was recommitted to a private psychiatric facility. ${ }^{308} \mathrm{He}$ died in 1999 after suffering three days of ill treatment and violent attacks from the facility staff. $^{309}$ The Court held that the Brazilian government was liable for Mr. Ximenes-Lopes' death because the State failed to "take care and prevent the breach of the right to life and humane treatment" and also failed to "regulate and monitor health care services, which are special duties derived from its obligation to guarantee the rights

Rights); "What is IACHR?" Inter-Amer. Comm'n H.R., available at http://www.cidh.oas.org/what.htm (last visited April 16, 2016).

295 "What is IACHR?", supra note 294.

296 Congo, supra note 161.

297 Id. at 2.

${ }^{298} I d$. at $9-10$.

299 Id. at $72-73$.

300 Article 5 states that persons have a right to have their physical, mental, and moral integrity respected. American Convention on Human Rights, supra note 282, at Article 5; See also Congo, supra note 161, at 9 59, 62, 68.

${ }^{301}$ Article 5(2) states that "no one shall be subjected to torture or to cruel, inhuman, or degrading punishment or treatment. All persons deprived of their liberty shall be treated with respect for the inherent dignity of the human person." American Convention on Human Rights, supra note 282, at Article 5.

302 Congo, supra note 161, at $\uparrow 59$.

${ }^{303} \mathrm{Id}$. at $910,19$.

${ }^{304}$ Article 4(1) states that "every person has the right to have his life respected. This right shall be protected by law and, in general, from the moment of conception. No one shall be arbitrarily deprived of his life." American Convention on Human Rights, supra note 282, at Article 4.

${ }^{305}$ Congo, supra note 161, at $\uparrow 24$.

306 See Ximenes-Lopes, supra note 94.

307 The Inter-American Commission on Human Rights (IACHR) and the Inter-American Court of Human Rights (IACtHR) are two distinct bodies within the Inter-American system. Both the Court and the Commission can decide individual complaints regarding human rights violations and both "may issue emergency protective measures when an individual or the subject of a complaint is in immediate risk of irreparable harm." However, the Commission is also responsible for monitoring human rights violations and promoting human rights and activities. The Court may issue advisory opinions on issues pertaining to the interpretation of the Inter-American instruments at the request of a Member State or organ of OAS. Inter-American Human Rights System, International Justice Resource Center, available at http://www.ijrcenter.org/regional/inter-american-system/ (last visited April 16, 2016).

${ }^{308} I d$. at 947 .

${ }^{309} \mathrm{Id}$. 
enshrined in Articles 4 and 5 of the American Convention on Human Rights." 310 The Court held that Brazil had a responsibility to monitor the health care of its patients and prevent vulnerability even though it was a private (not State-operated) institution. ${ }^{311}$

This case sent a clear message from the IACtHR that violations to a person, as well as his access to justice and due process, will not be tolerated by the international community. As a result of this landmark case, the municipality of Sobral in Brazil is now considered a model for mental health standards because it prioritizes residential therapy and/or outpatient care over institutionalized care and has abandoned all treatment programs that involve confinement. In fact, the municipality has been recognized nationally by the Ministry of Health as well as the pharmaceutical industry with the support of the Brazilian Psychiatric Association as the winner of the 2005 Social Inclusion Award for its commitment to protect its mentally disabled citizens. ${ }^{312}$

\section{B. Brazil}

\section{Mental Health Law and Brazil's Constitution}

Brazil's 1988 Constitution, for the first time, contained provisions protecting the rights of persons with disabilities. ${ }^{313}$ Article 5 establishes that it is the duty of the union, states, federal districts, and cities to care for public health and to protect people with disabilities. ${ }^{314}$ Article 5 also protects against torture or inhumane or degrading treatment of all its citizens, regardless of mental health, ${ }^{315}$ and guarantees all citizens the right to counsel. ${ }^{316}$ However, actual enforcement of the right to counsel is an entirely different matter. ${ }^{317}$

Article 203 of the constitution also requires the government provide social assistance to the "handicapped" and support their integration into community life. ${ }^{318}$ It further guarantees a monthly minimum wage to those with disabilities. ${ }^{319}$

Unfortunately, the Constitution does not specifically speak to the right to refuse treatment. However, over the past few decades, Brazil has made progress in reforming its mental health policies with strong support from the government and civil society. The passage of mental health legislation at national and state levels, the creation of community-based services, and the decentralization of the mental health system have all contributed to this reform. ${ }^{320}$ In the $1980 \mathrm{~s}$, Brazil began transitioning away from large psychiatric hospitals to more communitybased mental service programs, including implementing many primary care mental health projects such as group homes, rehabilitation programs, and workshops. ${ }^{321}$ Additionally, the Constitution established the Sistema Unico de Saúde (SUS) or Unified Health System. ${ }^{322}$ The SUS's three basic principles are (1) universality of health care,

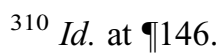

311 See generally Ximenes-Lopes, supra note 94.

312 WHO/WONCA Report, supra note 275, at 93.

${ }^{313}$ Report on the Situation of Human Rights in Brazil, Inter-Amer. Comm'n H.R., 1997, OEA/Ser.L/V/II 97 Doc. Rev. 1, Chapter X (1997), available at http:/www.cidh.org/countryrep/brazil-eng/chaper\%2010\%20.htm (last visited April 16, 2016) [hereinafter Brazil Report].

314 Constituição federal [C.F.] [CONSTitution] (Braz.) [2010]. This is the most current Constitution consisting of the 1988 Constitution with amendments from 1992 through 2010.

315 Id. at Article 5.

$316 I d$. (ensuring the arrested person assistance by his family and a lawyer, ensuring state-funded counsel for indigent defendants).

317 See e.g., T.A. Kelly, Exporting Western Law to the Developing World: The Troubling Case of Niger, 39 GEORGE Washington Int'l L. Rev., 321-366 (2006). After an exhaustive search, I was unable to find any information regarding the "real world" availability of counsel in Brazil.

318 Constituição federal [C.F.] [Constitution] (Braz.) [2010] at Article 203.

319 Id.

320 See generally Ministry of Health of Brazil, Pan American Health Organization/WHO, WHO-AIMS Report on mental health system in Brazil, Brasilia, Brazil: PAHO/WHO and Ministry of Health of Brazil; 2007, available at http://www.who.int/ mental_health/evidence/who_aims_report_brazil.pdf (last visited April 16, 2016) [hereinafter WHO-AIMS Report].

${ }^{32}$ See WHO/WONCA Report, supra note 275 , at 89.

${ }^{322} I d$. at 88 . 
(2) comprehensiveness of services, and (3) equity. ${ }^{323}$ As a result of the SUS, there are now local networks of health services, mainly primary care services, all over the country, including in rural areas. ${ }^{324}$

\section{Domestic Mental Health Legislation in Brazil}

Aside from the Constitution, Brazil currently has a relatively robust body of domestic legislation and policies that provide protection for people with mental disabilities. However, in the past, rather than adopting official documents to define mental health policies as the WHO requests, the government tended to accumulate the information and policies in reports and executive orders issued by the Brazilian Department of Health and then pass its own measures. ${ }^{325}$ For example, Law $10216^{326}$ of April 2001 legislatively helped reorient the Brazilian mental health care model to better protect people with mental disabilities and focus on access to mental health care. It also addressed issues including access to the least restrictive care; the rights of mental health service consumers, family members, and other care providers; voluntary and involuntary treatment; and mechanisms to oversee involuntary admission and treatment practices. ${ }^{327}$ Recently, Brazil has begun to implement even more mental health legislation. For example, the Inclusion Plan of 2014 was recently established. While it has yet to enter into force, the goal of the plan is to bring domestic legislation in line with the fundamental rights contained within the CRPD. ${ }^{328}$

\section{Brazil's Mental Health Law in Action}

There are many policies and programs that have been implemented to support people with mental disabilities within the country. For example, strengthening Brazil's community-based services was one of the country's main policy goals. This notion inspired the creation of Centers for Psychosocial Care (CAPS) - mental health centers equipped with outpatient and partial hospitalization services. ${ }^{329}$ According to the WHO, by 2006, Brazil had established 673 CAPS for adults, 66 special CAPS for children and adolescents, and 476 group homes for people with severe mental disabilities. ${ }^{330}$ There is also a recent trend toward allocating more mental health funding toward community services rather than psychiatric hospitals. ${ }^{331}$ One example of this is the Return Home Program ${ }^{332}$ enacted in 2003. This innovative program was established to deinstitutionalize long-term psychiatric patients and help them to integrate into society by providing patients with a monthly rehabilitation stipend transferred directly into their bank accounts. ${ }^{33}$ Currently, there are over 2,500 individuals receiving the rehabilitation benefit. ${ }^{334}$

Brazil has implemented some innovative programs to help deinstitutionalize people with mental disabilities and integrate them into society in a gradual manner. ${ }^{335}$ However, the nation is lacking an effective monitoring system for treatment and follow-up cases in outpatient facilities. ${ }^{336}$ Further, despite the improvements identified in Brazil's mental health policy, deaths are still occurring in psychiatric hospitals similar to the death that occurred in the Ximenes-Lopes case, and while the numbers presented on replacement services such as CAPS, Residential Therapeutic Facilities, and Communal Centers are promising, they are still insufficient to meet the demands of the population. 337

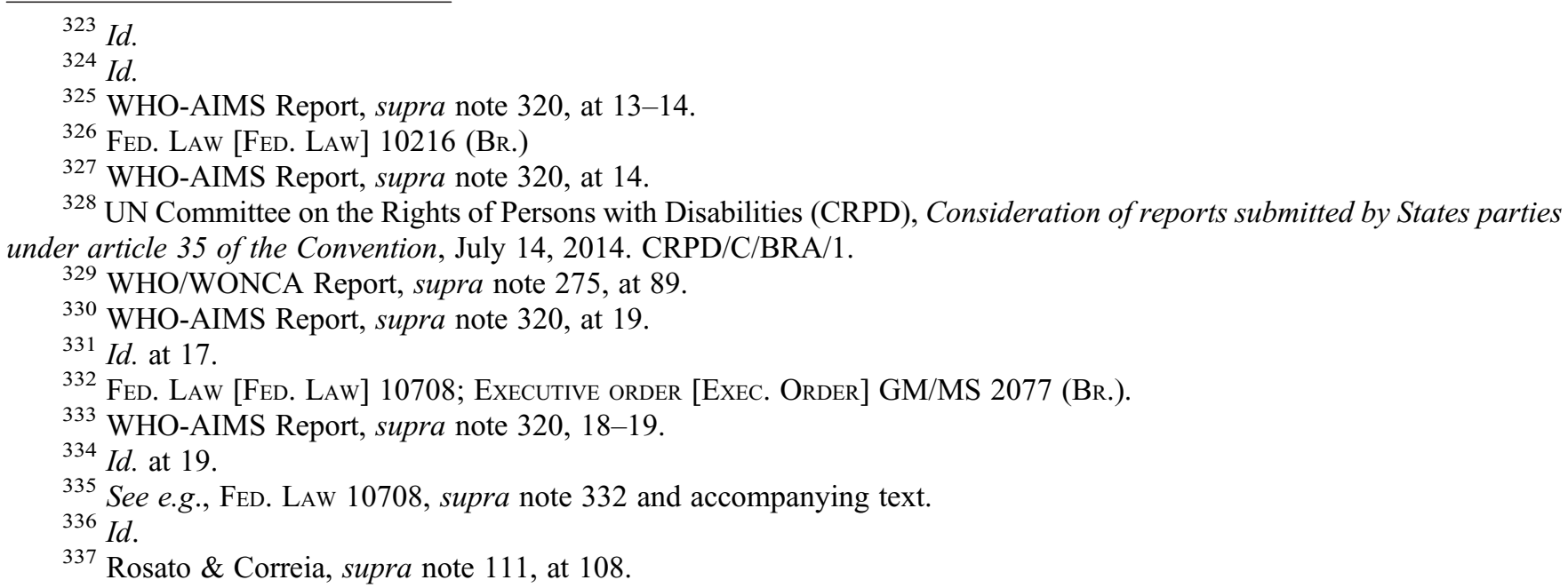


Although Brazil still has a long way to go, they are leaps and bounds ahead of other nations in terms of protecting the rights of persons with disabilities and should be used as a point of reference for other countries all over the world in moving toward better mental health care and support.

\section{Vi. Mental Health Law in Africa}

\section{A. Background on African Mental Health Law}

\section{Cultural Considerations}

Many African nations have relatively modern constitutions. This is due in large part to the history of colonialism on the continent followed by independence. Many of the new constitutions ${ }^{338}$ tend to have provisions that speak more to human rights and some even address the rights of persons with disabilities specifically, as compared to older constitutions where many human rights protections had to be interpreted by the courts or read into the constitution. ${ }^{339}$

Although many African nations are progressive in terms of their constitutions, there are many cultural and religious beliefs throughout Africa that negatively impact people with mental disabilities. For example, the group Human Rights Watch documented the horrific use of prayer camps in Ghana where people with mental disabilities face unimaginable conditions. ${ }^{340}$ Many people believe that individuals with mental disabilities have been cursed and that prayer camps may help heal them. Individuals sent to these prayer camps often spend days chained outside with little or no protection from the hot sun or rain, and are forced to eat, sleep, and defecate in the same spot. ${ }^{341}$

\section{African Charter on Human and Peoples' Rights}

The African Charter on Human and Peoples' Rights ${ }^{342}$ is an international human rights document that aims to promote and protect human rights and basic freedoms throughout Africa. Provisions of the Charter address civil commitment and the right to refuse treatment. Under Article 6, every individual has the right to liberty and to the security of his person. ${ }^{343}$ No one may be deprived of his freedom and the African Commission on Human and Peoples' Rights may investigate any reports of misconduct. ${ }^{344}$ Violations may be brought to a regional human rights court established in 2006 by the Charter. ${ }^{345}$

\section{Present Day Considerations for Africans with Mental Disabilities}

With the influence of the CRPD, many nations are moving toward community-based solutions, rather than institutionally-based solutions for persons with mental disabilities. However, African nations face challenges different from other nations in areas of funding, infrastructure, and shortages of health care workers. ${ }^{346}$

338 By "new constitutions," I am referring to the "new generation" of constitutions drafted or ratified since 1990.

339 See Tobias Pieter Van Reenen \& Helene Combrink, The UN Convention on the Rights of Persons with Disabilities in Africa: Progress after 5 Years, 8 SUR INT'L J ON Human Rights 133, 147 (noting that the "new generation" of African constitutions "clearly engage with the role that international human rights law should play at [the] domestic level").

340 See generally Human Rights Watch Report, supra note 36.

${ }^{341} \mathrm{Id}$.

342 Organization of African Unity (OAU), African Charter on Human and Peoples' Rights ("Banjul Charter"), June 27, 1981, CAB/LEG/67/3 rev. 5, 21 I.L.M. 58 (1982), available at http://www.achpr.org/instruments/achpr/ (last visited April 16, 2016).

343 Id. at Article 6.

344 Id. at Article 30.

${ }^{345}$ See Organization of African Unity, Protocol to the African Charter on Human and Peoples' Rights on the Establishment of an African Court on Human and Peoples' Rights, June 9, 1998, OAU Doc. OAU/LEG/EXP/AFCHPR/PROT (III); PERLIN ET AL., Documents Supplement, supra note 160, at 249-83; see also Olufemi Amao, The African Regional Human Rights System, in International Human Rights Law: Six Decades After the UDHR and Beyond 3, 235 (Mashood A. Baderin \& Manisuli Ssenyonjo eds., 2010).

${ }^{346}$ Peter Bartlett et al., Mental Health Law in the Community: Thinking About Africa, 5 Int J Ment Health Syst 21,21 (2011). 
A successful movement toward community-based treatment solutions requires an abundance of health care workers. African nations tend to have limited psychiatrists, psychiatric nurses, psychologists, and social workers. ${ }^{347}$ In terms of funding, African nations tend to have a lower percentage of State funding allocated toward mental health programs than other nations across the globe. ${ }^{348}$ Further adding to these issues is the fact that communities within many African nations tend to be scattered throughout the country with limited public transportation, access, and infrastructure. ${ }^{349}$

\section{Access to Adequate Counsel}

Access to adequate counsel on the continent of Africa has been addressed by the African Commission on Human and Peoples' Rights, which has passed a series of resolutions regarding the right to counsel. ${ }^{350}$ Among these documents is the Principles and Guidelines on the Right to a Fair Trial and Legal Assistance in Africa, (2003), ${ }^{351}$ which provides "prompt access to a lawyer and, unless the person has waived this right in writing, [he is] under no obligation to answer any questions or participate in any interrogation without a lawyer being present." 352 These Principles emphasize that States shall ensure all persons receive equal access to lawyers regardless of, among other things, disability, race, origin, sex, gender, and language. ${ }^{353}$ Despite these guidelines, access to legal aid at all stages of the justice system is generally unavailable in many African nations. Even where formal legal aid programs are available, coverage is routinely inadequate. Indigent defendants, victims, and complainants are regularly unable to prepare and argue a defense, seek assistance, or seek legal advice on filing a claim. This essentially ensures that the poor are effectively "priced out" of the criminal justice system. ${ }^{354}$

\section{Adjudication of African Mental Health Law}

Purohit and Moore v. Gambia ${ }^{355}$ (2003) was a landmark case heard by the African Commission on Human and Peoples' Rights. Paul Moore, a student and mental health advocate, was visiting a mental health facility in Gambia and was appalled by the patient treatment provided by the staff. He filed suit with the Commission as a third party on behalf of current and future patients claiming that the legislation (the Lunatic Detention Act) was outdated and not in conformity with the African Charter. ${ }^{356}$ Normally, a domestic tribunal must hear cases and all remedies must be exhausted prior to being allowed to appeal to the Commission. In this case, the Commission noted that redress was not available or realistic for these complainants via domestic law and thus the case was admissible directly before the African Commission on Human and Peoples' Rights. ${ }^{357}$ In its holding, the Commission relied on the MI Principles providing that it is the State's obligation to undertake the responsibility to bring domestic laws

347 Id. at 21.

348 World Health Organization, The World Health Organization Report 2001- Mental Health: New Understanding, New Hope (2001).

349 Bartlett et al., supra note 346 , at 22 .

${ }^{350}$ U.N.O.D.C. (2011), Access to Legal Aid in Criminal Justice Systems in Africa: Survey Report, Vienna, 4-5, available at

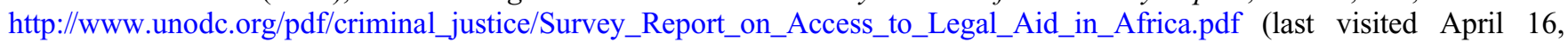
2016).

351 African Union, African Commission's Principles and Guidelines on the Right to a Fair Trial and Legal Assistance in Africa, 2003, DOC/OS(XXX)247, available at http://www1.umn.edu/humanrts/research/ZIM\%20Principles_And_G.pdf (last visited April 16, 2016) [hereinafter African Commissions’ Principles].

${ }^{352} I d$. at Sec. $\mathrm{A}(2)$.

${ }^{353}$ Id. at Sec. G(a).

354 U.N.O.D.C., supra note 350 , at 21.

355 Purohit and Moore v. Gambia, African Commission on Human and Peoples' Rights, Comm. No. 241/2001 (2003).

356 See generally id.

${ }^{357}$ Eva Szeli, PhD, JD, Adjunct Professor of Law, New York Law School, Psychology Faculty, Arizona State University, Class Lecture: Comparative Disability Law III: Latin American and Africa, at New York Law School (April 15, 2014), available at, http://nyls.mediasite.com/mediasite/Play/27d067994c44434e9388b22141b78f5e1d?catalog=09b3d409-d7b9-470c-bfae8b3e2ea43e27 (last visited April 16, 2016). 
in line with international or regional documents that have been ratified. ${ }^{358}$ This is an important example of a regional human rights body holding a State responsible for inadequate domestic legislation for people with mental disabilities.

\section{B. Kenya}

\section{Mental Health Law and Kenya's Constitution}

The Constitution of Kenya, ${ }^{359}$ promulgated in 2010, provides several specific provisions for persons with disabilities. ${ }^{360}$ It states that persons with disabilities are entitled to be treated with dignity and respect and cannot be demeaned. ${ }^{361}$ It provides access to educational institutions and facilities for persons with disabilities, and not only calls for integration into society but also requires people with disabilities have access to all places including public transportation and information. ${ }^{362}$ It further obligates the government to make use of sign language, Braille, and other forms of communication available to people with disabilities ${ }^{363}$ including access to devices that help overcome disability constraints. ${ }^{364}$ Further, the Constitution provides the State shall ensure progressive implementation into governing bodies by mandating that 5 percent of the public elective and appointive bodies are persons with disabilities. ${ }^{365}$

\section{Domestic Mental Health Legislation in Kenya}

Although the Constitution does not specifically speak to the right to refuse treatment, there is domestic law in Kenya that speaks to that right. ${ }^{366}$ The Mental Health Bill ${ }^{367}$ of 2014 (which replaced the Mental Health Act of 1989) 368 makes references to the human rights of those with mental disabilities and establishes a Mental Health Board to monitor and enforce those rights. In the past, similar boards have been written into legislation yet they have never been implemented. ${ }^{369}$ It appears that the 2014 Mental Health Board has yet to be established and just like past boards has seemingly fallen by the wayside.

According to the new Act, where a person with a mental disability is capable of making an informed decision, the health care provider shall inform the patient of his or her right to choose an appropriate treatment of his or her own choice and shall obtain consent in writing prior to the administration of such treatment. ${ }^{370}$ If a person is incapable of making an informed decision regarding treatment, consent must be obtained from the person's representative. ${ }^{371}$

The individual is also entitled access to treatment information ${ }^{372}$ and has the right to participate in forming his or her own treatment plan. ${ }^{373}$ The individual is entitled to choose or appoint his own representative if needed and the representative may help if the individual is incapable of participating in the formation of a treatment plan. ${ }^{374}$ Finally, the Act provides that no mental health care, treatment, or admission shall be given to persons with

\footnotetext{
${ }^{358}$ Purohit and Moore, supra note 355 , at $\$ 60$.

359 Constitution (2010) (Kenya).

360 Id. at Article 54.

361 Id. at Article 54(a).

${ }^{362}$ Id. at Article 54(b), (c).

363 Constitution (2010) (Kenya) at Sec. 54(d).

364 Id. at Article 54(e).

${ }^{365}$ Id. at Article 52(2).

${ }^{366}$ Hannah Gibson, Reforming Kenya's ailing mental health system, AfricA ReSEARCh InstituTe (June 23, 2013), available at http://www.africaresearchinstitute.org/blog/mental-health-in-kenya/ (last visited April 16, 2016).

${ }^{367}$ Mental Health Act (2014) KenYa Gazette Supplement No. 61.

368 Mental Health Act, Act No. 10 (1989)(Kenya).

${ }^{369} I d$.

${ }^{370}$ Mental Health Act (2014), supra note 368, at Article 18(1).

371 Id. at Article 18(2).

${ }^{372}$ Id. at Article 19(1).

${ }^{373} \mathrm{Id}$. at Article 28(1).

374 Mental Health Act (2014), supra note 367, at Article 28(2).
} 
mental disabilities without informed consent or the informed consent of the representative. ${ }^{375}$ Valid informed consent must be documented and must satisfy the following elements:

a) the person (or the representative) must be competent to give the consent;

b) consent must be given freely without threats or improper influence;

c) there must be appropriate and adequate disclosure of all relevant information regarding treatment including information on the kind, purpose, likely duration, effects, and expected benefits of the treatment; and

d) where available, choices shall be given to persons with disabilities. ${ }^{376}$

Further, emergency treatment is only permitted when there is an "immediate and imminent danger to the health and safety" of the person with a disability or others and the nature of that danger shall be such that urgent care and treatment are required to stabilize the person. ${ }^{377}$ In such a situation, the emergency treatment 1) shall not last longer than necessary to stabilize the person, 2) shall not exceed 72 hours, and 3) is only allowed to the extent necessary for treatment. ${ }^{378}$

Where treatment is provided, persons with mental disabilities shall not be physically restrained or secluded except in accordance with the law or a set provision. ${ }^{379}$ Seclusion and restraint shall only be used where it is "strictly necessary" to prevent immediate and imminent harm to self or others and shall not be prolonged beyond when strictly necessary for the individual to co-habit peacefully with others. ${ }^{380}$ The reasons, nature, and extent of the seclusion shall be recorded and kept in the individual's records, ${ }^{381}$ and the representative of the person with a mental disability shall be promptly notified of the use of seclusion or restraint. ${ }^{382}$ Seclusion and restraint may not be used as punishment or convenience, but shall only be used as a last resort and the "necessary treatment shall be availed." 383

The Patients' Rights Charter (2013), ${ }^{384}$ issued by the Kenyan Ministry of Health, specifically addresses the right to refuse treatment via Article 6 which provides that any individual may refuse, withdraw, or withhold treatment as long as that refusal does not create an immediate danger to self or others and provided that the person's competency and consciousness has been taken into account. ${ }^{385}$ This is a vital document in that it is the first official piece of Kenyan legislation that protects the rights of individuals seeking treatment in hospitals and mental health care facilities to refuse that treatment should they choose to do so. ${ }^{386}$

\section{Kenya's Mental Health Law in Action}

The right to counsel in Kenya seems bleak. While the African Commissions' Principles and Guidelines on the Right to Counsel have provisions pertaining to the right to counsel ${ }^{387}$ there are still many logistical obstacles to implementing that right in Kenya. For example, a recent study by the World Bank, and in association with law societies, found that of the Kenyan population of approximately 39 million, more than three quarters of the population live in rural areas and there are less than 4,000 lawyers in the entire nation. ${ }^{388}$ With numbers like this, it is practically impossible to provide adequate legal counsel to the entire population.

375 Id. at Article 30(1).

376 Id. at Article 30(2).

377 Id. at Article 34(1).

378 Mental Health Act (2014), supra note 367, at Article 34(1).

${ }^{379}$ Id. at Article 36(1).

${ }^{380}$ Id. at Article 36(3).

381 Id. at Article 36 (4).

${ }^{382}$ Mental Health Act (2014), supra note 367, at Article 36(6).

${ }^{383}$ Id. at Article 37(1)(b).

${ }^{384}$ Ministry of Health, The Kenya National Patients' Rights Charter (2013), available at http://integratepc.org/wp-content/ uploads/2013/10/Kenya-Patients-Rights-Charter.pdf (last visited April 16, 2016).

385 Id. at Article 6.

386 Ally Jamah, New Charter to Protect Patients from Medical Negligence, STANDARd Media (May 13, 2013), available at http://www.standardmedia.co.ke/health/article/2000083482/new-charter-to-protect-patients-from-medical-negligence (last visited April 16, 2016).

387 See African Commissions' Principles, supra note 351, at Article A, G-H.

${ }^{388} I d$. at 12. 
In any event, Kenya has recently established progressive mental health legislation, which specifically includes protections for the right to refuse treatment for patients with mental disabilities. Fortunately, much of this legislation is on par with current international standards. However, it is still very new, and thus there is little information as to its efficacy. The question that remains is how effective the legislation is, and whether it is being enforced. This is the biggest issue with international human rights in general, and specifically mental disability law. ${ }^{389}$

\section{Comparative Analysis of the United States, Brazil, and Kenya}

The state of mental disability law in many parts of the world today reveals a pattern and practice of ongoing abuses that is "reminiscent of the state of American mental health facilities 35 or more years ago." 390 According to Oliver Lewis, "[m]ainstreaming 'mental disability rights' into our regular human rights agenda is a crucial step towards thinking seriously about protecting the rights of people with disabilities." ${ }^{291}$ As a result of the CRPD and other international human rights documents and systems, there have been important advancements in the area of mental disability law and many mental disability rights laws in Brazil and Kenya are on par with international human rights standards. However, it should be noted that while both Brazil and Kenya are on the way toward alignment with the CRPD standards, they are not quite there yet.

The United States has developed more case law than any other nation but little legislation or constitutional protections that speak specifically to the right to refuse treatment. The United States, with one of the oldest constitutions in the world, does not specifically address many of the hotly debated issues of today such as gay marriage or abortion. It also does not speak to the rights of persons with disabilities. Further, the United States is unlikely to rewrite the Constitution. For example, there have only been twenty-seven amendments since its enactment in $1787 .{ }^{392}$

One of the biggest obstacles not only in these three nations, but all over the world, is realistic access to adequate counsel, ${ }^{393}$ which is an essential part of protecting the rights of persons with mental disabilities. ${ }^{394}$ The United States has protections for the right to counsel generally within the Constitution, however, case law has not yet clearly mandated a right to adequate and effective counsel for persons with mental disabilities. The African Commissions' Principles and Guidelines on the Right to Counsel includes express provisions regarding the right to counsel generally, ${ }^{395}$ however, Kenya has yet to implement any domestic provisions that speak to this right. Coupled with the discrepancy between the population and the number of lawyers in the country, the African Commissions' provision on the right to counsel is in essence unworkable. Brazil's Constitution also contains a provision for the right to counsel. ${ }^{396}$ While Brazil's domestic legislation is somewhat nontraditional, the country has made substantive efforts to comply with CRPD standards and has worked to deinstitutionalize individuals in a gradual, community-based manner. Because both Kenya and Brazil have signed and ratified the CRPD, I remain hopeful that their domestic legislation will fall in step with the widely accepted international standards and that the legislation will actually be implemented and enforced as it was designed to do.

\section{Conclusion}

Over the past few years there have been drastic improvements for the protection of persons with mental disabilities in international human rights law, especially with conventions like the CRPD. The MI Principles established minimums for civil commitment and included provisions that protected the right to refuse treatment, but there was no

389 See Fischer, supra note 12 , at 183.

390 Bruce J. Winick, Therapeutic Jurisprudence and the Treatment of People with Mental Illness in Eastern Europe: Construing International Human Rights Law, 21 N.Y.L. Sch. J. InT'L \& Comp. L. 537, 538 (2002).

${ }^{391}$ Lewis, supra note 134, at 316.

392 The Constitution of the United States: Amendments 11-27, National Archives and Records Administration, available at http://www.archives.gov/exhibits/charters/constitution_amendments_11-27.html (last visited April 16, 2016).

393 Perlin, The Universal Factors, supra note 38, at 342.

${ }^{394}$ It is essential that advocates bring cases to international courts to articulate this specific right if disability law is to

flourish. Perlin, Silenced, supra note 140, at 163.

395 See generally, African Commissions' Principles, supra note 351.

396 Constituição federal [C.F.] [Constitution] (Braz.) [2010] at Article 5. 
express international hard law on the right to refuse treatment until the CRPD. The CRPD brings new hope for the rights and general dignity of persons with mental disabilities.

The United States may be viewed as a world leader in some areas, but the reality is that the United States is lagging behind when it comes to policies and laws protecting the right to refuse treatment for people with mental disabilities. One blatant example is the fact that the United States still has not ratified the CRPD although it signed it in 2009. Where generally the Inter-American system seems to have more regulations and case law on mental disabilities than the African system, which tends to be underfunded, there are many nations in Latin America lagging behind on protective mental health legislation as well. Brazil's Constitution is sparse regarding the rights of persons with mental disabilities, let alone the right to refuse treatment, where Kenya's updated Constitution has specific rights for persons with mental disabilities but does not speak to the right to refuse treatment. Kenya's domestic legislation speaks to the right to refuse treatment in great detail, but faces greater barriers in enforcing such protections.

Documents such as the CRPD mandate ratified State Parties to amend or create legislation in line with international standards. ${ }^{397}$ However, the right to refuse treatment is still a complex issue, as we have seen, and there are many competing interests at stake. Just because laws are on the books, does not mean they are enforced. Although some nations require consent to treatment, in everyday workings in hospitals, especially in rural areas with less trained staff and less monitoring, these rights are routinely ignored. ${ }^{398}$ That is why it is imperative to have regional systems in place that help monitor and enforce rights for persons with mental disabilities. However, as Professor Perlin points out, these regional systems are also in effect useless without access to adequate counsel. ${ }^{399}$ "Simply put, if active, trained counsel is not provided for patients seeking to interpose this right, then the right becomes nothing more than a paper document: useless and meaningless (and perhaps, counterproductive) in the 'real world." 400

One of the most valued liberties in a civilized society is autonomous decision-making in matters affecting the body and mind. ${ }^{401}$ Unfortunately, this is not a reality for a majority of the people with mental disabilities all over the world. There is still much progress to be made to ensure the protection of the rights of persons with mental disabilities regarding the right to refuse treatment. However, I remain optimistic. Documents such as the CRPD and recent decisions in regional human rights courts lead me to believe that mental disability rights advocates are not giving up anytime soon. I have to believe that someday "no" really will mean "no" for persons with mental disabilities in institutions.

397 CRPD, supra note 12, at Article 4.1(a).

398 Fischer, supra note 12, at 185; see also Lewis, Paper, Practice, Promise, supra note 62, at 295; see also PERLIN, SILENCED, supra note 140 , at 86.

399 See generally Perlin, The Universal Factors, supra note 38.

${ }^{400}$ Michael L. Perlin, “And My Best Friend, My Doctor/ Won't Even Say What It Is I've Got”: The Role and Significance of Counsel in Right to Refuse Treatment Cases, 42 SAN Diego L. Rev. 735, 737 (2005).

401 See Immanuel Kant, Fundamental Principles of the Metaphysics of Morals, In Problems Of Moral Philosophy 2336 (Paul W. Taylor ed., 2d ed. 1972); Charles Friedman, An Autonomy of Values: Problems of Personal and Social Choice 34-39, 138 (1970). 